\title{
Proofs of Long-Distance Relations between Central Europe and Inland Iberian Peninsula during Neolithic and Bronze Age. Evidences from the Material Culture of the Site of El Portalón (Sierra de Atapuerca, Burgos, Spain)
}

\author{
Alfonso Alday ${ }^{*}$, Amalia Pérez-Romero², José-Miguel Carretero ${ }^{2,3}$, \\ María Ángeles Galindo-Pellicena ${ }^{3,4}$, Gema Adán², Juan-Luis Arsuaga ${ }^{3,4}$ \\ ${ }^{1}$ Departamento de Geografía, Prehistoria y Arqueología, Universidad del País Vasco, Vitoria, Spain \\ ${ }^{2}$ Laboratorio de Evolución Humana, Departamento de Ciencias Históricas y Geografía, Universidad de Burgos, \\ Burgos, Spain \\ ${ }^{3}$ Centro UCM-ISCIII de Investigación sobre Evolución y Comportamiento Humanos, Madrid, Spain \\ ${ }^{4}$ Departamento de Paleontología, Universidad Complutense de Madrid, Madrid, Spain \\ Email: *a.alday@ehu.eus
}

Received 3 July 2015; accepted 15 November 2015; published 18 November 2015

Copyright (C) 2015 by authors and Scientific Research Publishing Inc.

This work is licensed under the Creative Commons Attribution International License (CC BY).

http://creativecommons.org/licenses/by/4.0/

(c) (i) Open Access

\section{Abstract}

El Portalón of Cueva Mayor is one of the present-day entrances to the Cueva Mayor-Cueva del Silo karst system located in the Sierra de Atapuerca (Burgos, Spain). It is an important archaeological site with extended Holocene occupation which has been subjected to a number of excavations since the nineteen seventies. From its significant collection of bone and antler industry, for this work, we have chosen artefacts indicating local production and others evidencing contact between this part of the Iberian Peninsula and other areas of the Mediterranean Basin. Wishing to emphasise this symbiotic relationship, we have likewise presented a special collection of Neolithic Boquique pottery. The data confirm that, far from being occasional, the relationship of the groups living in the area around the Atapuerca Mountains continues unbroken for several cultural episodes.

\footnotetext{
${ }^{*}$ Corresponding author.
}

How to cite this paper: Alday, A. et al. (2015). Proofs of Long-Distance Relations between Central Europe and Inland Iberian Peninsula during Neolithic and Bronze Age. Evidences from the Material Culture of the Site of El Portalón (Sierra de Atapuerca, Burgos, Spain). Advances in Anthropology, 5, 294-323. http://dx.doi.org/10.4236/aa.2015.54023 


\section{Keywords}

Bone Industry, Holocene, Atapuerca Mountains, European Contacts, Pottery, Worked Human Bone

\section{Introduction and Objectives}

Each recent prehistoric site is valued for its size, the quality of its archaeological record and the exactness of a classification backed up by stratigraphy and absolute chronology. It is also valued for its capacity to be integrated in its geographical and cultural context. In this framework, two kinds of elements are to be found in its material inventory. On one hand, artefacts making up common household items, created, brought to, reactivated and abandoned on the site, and on the other hand, artefacts belonging to the social or ritual sphere (ornaments, offerings, etc.) for a more prolonged use and with sporadic and/or special functions. The latter need more time to be made and imply foreign and good quality raw materials, a social cost incentivising their exchange.

In the Atapuerca mountain range (North of the Iberian Peninsula), a karst system called Cueva Mayor-Cueva del Silo has developed providing support for several Quaternary sites which together make up one of the largest records in European prehistory. Along with its well-known archaeological remains from the Pleistocene (Arsuaga et al., 1997; Bermúdez de Castro et al., 1999), it also yields others from the Holocene (Figure 1). At Cueva Mayor, occupations during the Holocene developed not only in its large entrance, called El Portalón (Figure S1), but also in the inner galleries as in Galería del Sílex, a place for burials and artistic purposes (Apellániz \& Domingo, 1987).

The archaeological nature of El Portalón has been known since the end of the nineteenth century and an ongoing intervention has yielded a stratigraphy with 11 levels and a potential of over six metres (Figure 2 and Figures S1-S5 and Note S1)

The archaeological material record and a long radio-chronological series situate the occupations from the end of the Pleistocene to the Middle Age (Table 1 and Table S1) (Carretero et al., 2008).

Table 1. Radiocarbon dates of the South profile of El Portalón sequence.

\begin{tabular}{|c|c|c|c|c|c|c|c|}
\hline Elements & Cultural Allocation & Level & $\begin{array}{c}\text { Sample } \\
\text { Number }^{(1)}\end{array}$ & Material & Reference & Years BP & $\begin{array}{l}\text { Years cal BC } \\
\text { (2 Sigma) }\end{array}$ \\
\hline \multirow{4}{*}{$\begin{array}{l}\text { Pins/needles } \\
\text { and V-perforated } \\
\text { buttons }\end{array}$} & \multirow{2}{*}{ Middle Bronze Age } & \multirow{2}{*}{3} & III.1 & Organic sediment & Beta-153,360 & $3330 \pm 70$ & 1760 to 1440 \\
\hline & & & III. 2 & Bone & Beta-222,336 & $3560 \pm 50$ & 2030 to 1750 \\
\hline & & \multirow[b]{2}{*}{4} & IV.1 & Charcoal & Beta-212,188 & $3490 \pm 40$ & 1910 to 1700 \\
\hline & & & IV. 2 & Charcoal & Beta-153,361 & $3680 \pm 40$ & $\begin{array}{l}2190 \text { to } 2170 \\
2150 \text { to } 1940\end{array}$ \\
\hline \multirow{4}{*}{$\begin{array}{c}\text { Arrowheads } \\
\text { and } \\
\text { bipointed } \\
\text { objects }\end{array}$} & \multirow{4}{*}{ Early Bronze Age } & \multirow{4}{*}{5} & V.1 & Charcoal & Beta-153,362 & $3630 \pm 40$ & $\begin{array}{l}2130 \text { to } 2080 \\
2060 \text { to } 1890\end{array}$ \\
\hline & & & V.2 & Tooth & Beta-224,079 & $3670 \pm 40$ & $\begin{array}{l}2190 \text { to } 2180 \\
2140 \text { to } 1940\end{array}$ \\
\hline & & & V.3 & Charcoal & Beta- 184,843 & $3700 \pm 70$ & 2290 to 1900 \\
\hline & & & Arrowhead $^{(2)}$ & Bone & Beta-269,493 & $3630 \pm 40$ & $\begin{array}{l}2190 \text { to } 2180 \\
2140 \text { to } 1940\end{array}$ \\
\hline $\begin{array}{c}\text { Awl on } \\
\text { human bone }^{(3)}\end{array}$ & $\begin{array}{l}\text { Chalcolithic-Bronze } \\
\text { Age transition }\end{array}$ & 6 & ATP $08-8$ & Bone & Beta-153,363 & $3910 \pm 70$ & 2580 to 2200 \\
\hline Arrowheads & Chalcolithic & $7 / 8$ & VII.1 & Tooth & Beta-197,389 & $4440 \pm 50$ & 3340 to 2920 \\
\hline \multirow{3}{*}{$\begin{array}{l}\text { Pottery with } \\
\text { boquique } \\
\text { decoration }\end{array}$} & \multirow{3}{*}{ Neolithic } & \multirow{3}{*}{9} & IX.1 & Charcoal & Beta-184,841 & $4990 \pm 40$ & $\begin{array}{l}3930 \text { to } 3860 \\
3810 \text { to } 3670\end{array}$ \\
\hline & & & IX.2 & Charcoal & Beta-184,842 & $5230 \pm 40$ & $\begin{array}{l}4150 \text { to } 4120 \\
4070 \text { to } 3960\end{array}$ \\
\hline & & & IX.6 & Organic sediment & Beta-222,340 & $6270 \pm 40$ & $\begin{array}{l}5320 \text { to } 5210 \\
5170 \text { to } 5080\end{array}$ \\
\hline
\end{tabular}

(1) = Sample number indicated in Figure 2; (2) = Specimen from El Portalón directly dated; (3) = Specimen directly dated studied in this work (Figure 11). 


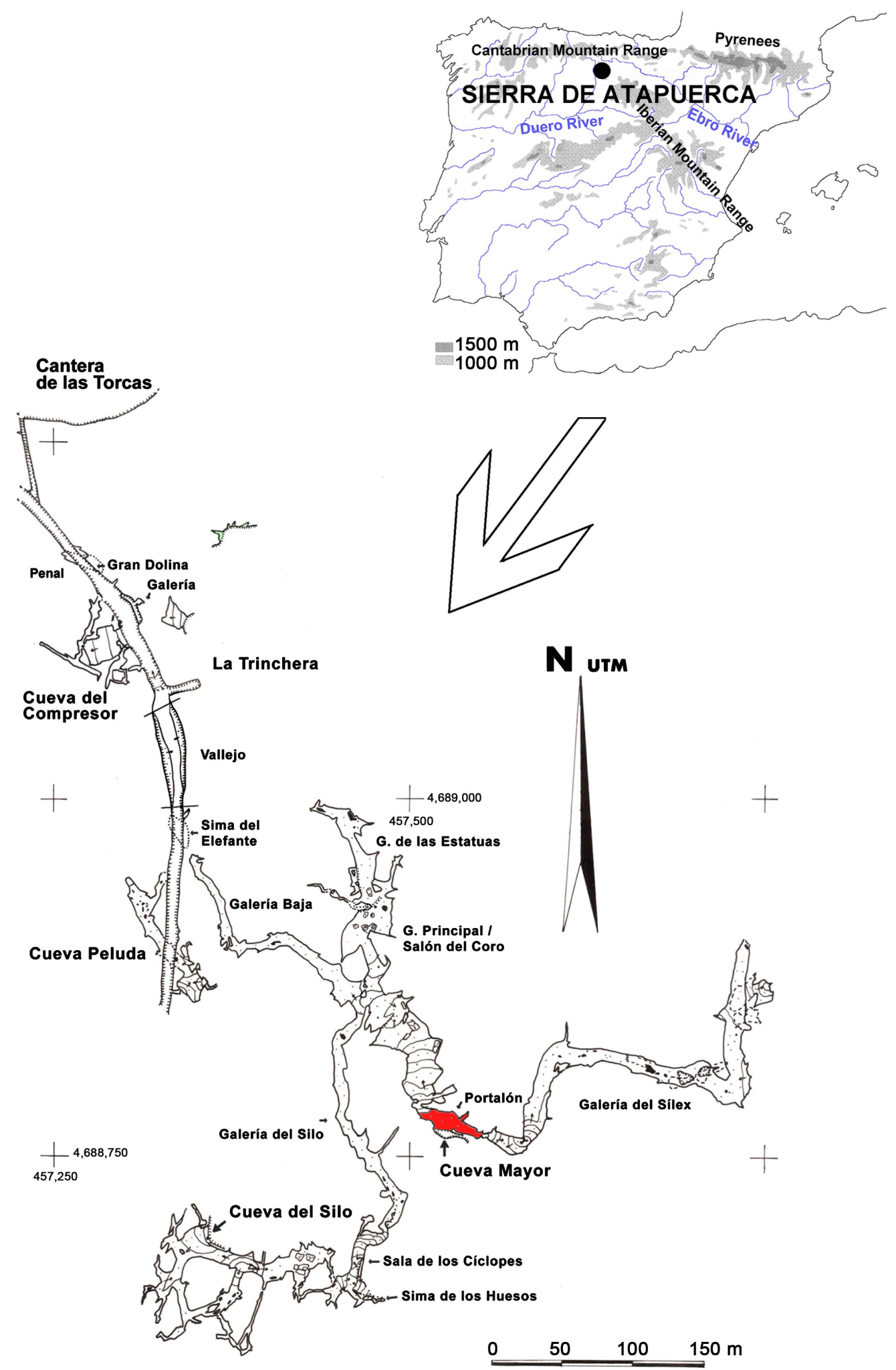

Figure 1. Geographic situation of the Sierra de Atapuerca and map of the Trinchera del Ferrocarril and Cueva Mayor-Cueva del Silo karst system showing the location of El Portalón in relation to other Atapuerca Pleistocene and Holocene sites such as Gran Dolina, Galería, Sima del Elefante, Sima de los Huesos, Galería del Sílex and Galería de las Estatuas. 


\section{ARCHAEOLOGICAL HEIGHT}

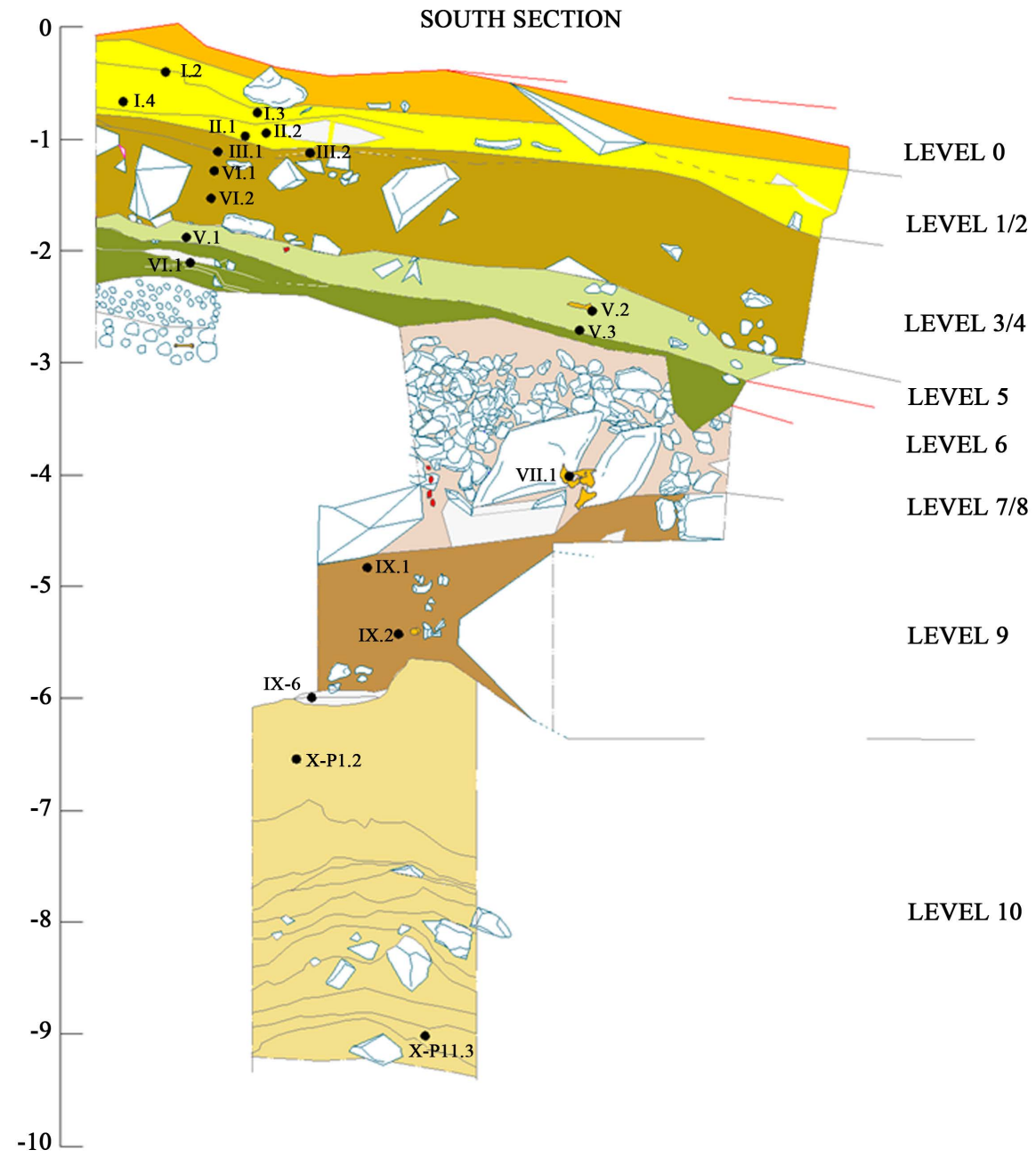

Figure 2. Stratigraphical sketch of the South profile of El Portalón. Black dots indicate the position of the samples for radiocarbon dating labelled as in Table 1.

El Portalón would have had a variety of uses throughout its long period of occupation, as a dwelling, a cattle shelter and burial site, activities that would have been complemented by those carried out in Galería del Sílex or nearby caves as El Mirador (Vergés et al., 2008), as well as on grazing grounds and arable lands on the Sierra.

The purpose of this work is to provide an overview of a collection of pottery and bone objects belonging from the site of El Portalón by examining them through time (from the Neolithic to the Bronze age) and within a large geographical framework. At the same time, we shall discover the keys to the occupation of this cave entrance and its link with the prehistory of the region.

\section{Material and Methods}

The collection of pottery from El Portalón is as varied as it is large as regards form and decoration. Due to its special interest, we have brought together pottery adorned using the Boquique technique with Neolithic chronology (Alday et al., 2009) (Figure 3 and Figure S6).

The bone industry inventory from El Portalón includes in excess of two hundred objects distributed over several levels, cultural units and industrial categories (Table S2). In this study we shall describe the characteristics of the bi-pointed artefacts, needles/pins, V-perforated buttons, arrowheads and a special human bone awl. Some of them are identified and described here for the first time (for nomenclature and typology Adán, 1997; Barandiarán, 1967; Camps-Fabrer, 1990; Rodanés, 1987; Voruz, 1987). 

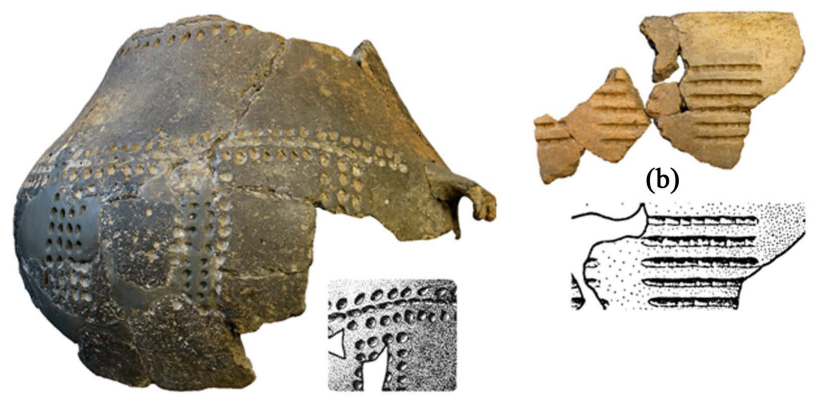

(b)

(a)

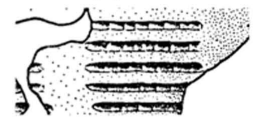

(a)

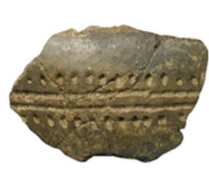

(c)

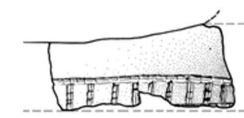

(d)

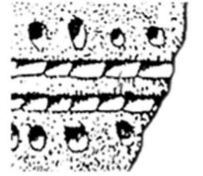
o d y

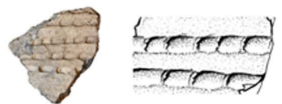

(e)

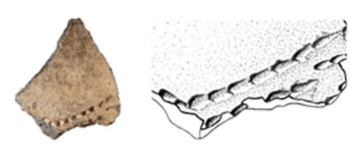

(f)

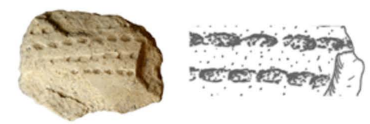

(g)

Figure 3. Neolithic pottery with boquique and pseudoboquique decoration from Galería del Sílex. ((a)-(d)) and El Portalón ((e)-(g)). Decorative motifs: metope (a); horizontal lines ((b), (c), (e), (g)); angled lines (f) and sequence-ladder $(\mathrm{d})$. The scale is $5 \mathrm{~cm}$.

\section{Results}

\subsection{Neolithic Pottery with Boquique Decoration}

The excavation of an old "mine shaft" (see Figure S2 and Figure S3) redeemed 16 fragments with this decoration in simple-shaped recipients. Their production style brings to mind a group or set (family resemblance), because of the use of traditional Boquique (lines and dots) (Figures 3(a)-(c)) and pseudo-Boquique (Figures 3(d)-(g)), and the simplicity of iconographic designs (horizontal lines, framed or not, by prints (Figure S6).

The properties of the paste, the application of temper and the technique used in its making, all point to local craftsmanship.

The Boquique inventory is equivalent to that from the Galería del Sílex (Apellániz \& Domingo, 1987; Alday et al., 2009; Ortega et al., 2008), where surface finds total over 6,000 fragments. Among them, a dozen pieces ascribed to Neolithic were decorated using the Boquique technique (Figure S6) and reiterate themes found in El Portalón, although with more complex iconographies. At both sites the same paste and similar processes were used. Also in El Mirador Cave, Vergés et al. (2008) report similar pottery from Neolithic levels (confirmed using radio chronology) that reveal the same themes and techniques.

The Boquique production of the Atapuerca Range is produced locally with precise technical, formal and decorative procedures for social identification over a broad territory. In fact, Neolithic Boquique pottery is distributed over a large part of the interior of the Iberian Peninsula and on the Atlantic coast, an alternative to the cardial pottery found along the Mediterranean (Figure 4). They are ceramic domains of the early Iberian Neolithic which are related to the different influences reaching the Iberian Peninsula in that period and to the positions adopted by those living in each place. 


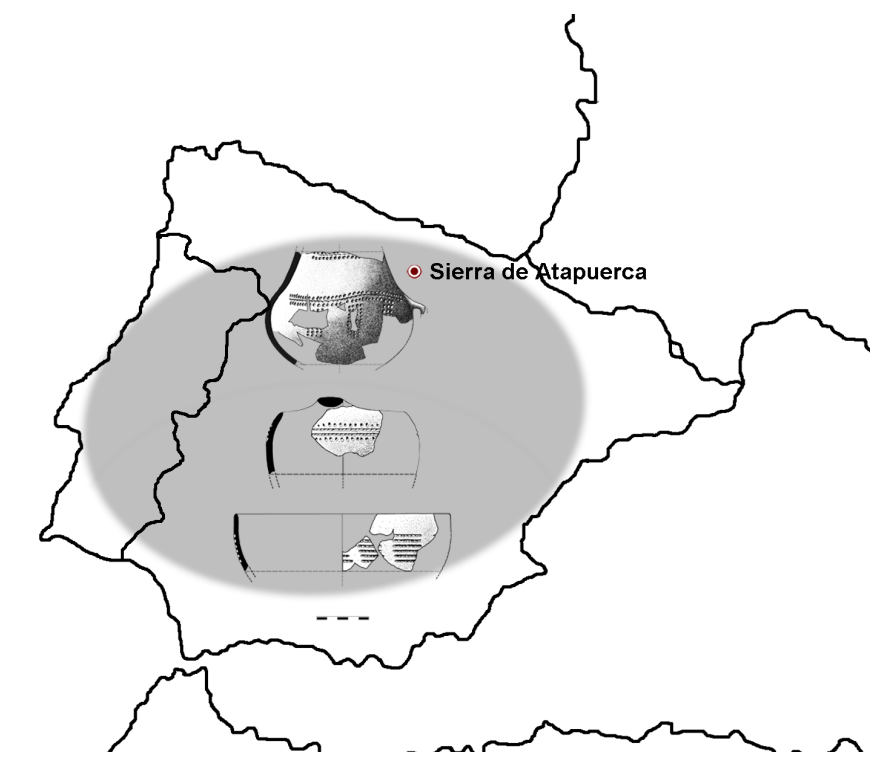

Figure 4. Geographic distribution of the Neolithic pottery with boquique decoration in the Iberian Peninsula.

\subsection{Pins/Needles}

Two decorative bone pins (Figure 5(a) and Figure 5(b) and Figure S7) are carefully made objects with very precise typological characters (curved rods pointed at one end, with a small perforation at the opposite end). Our stratigraphic references take us up to the Middle Bronze Age.

There are two more cases in Iberia: in the Sakulo dolmen and in Cueva Lóbrega, and we tracked European similarities in the Rhone-Rhine corridor, in North-Eastern Italy and in Switzerland (Barge, 1982; Camps-Fabrer et al., 1990; Delibes, 1983). They were likewise inspired by the Belier-type needles, common in these regions and presents in the Iberian burial sites of La Atalayuela and Tres Montes, very near to El Portalón (Andrés et al., 2007; Barandiarán, 1978) (Table S3). These bone pins reflect the relationship those exploiting the Atapuerca Mountain Range and its region had with communities located in the heart of Europe.

\subsection{Bi-Pointed Objects}

Six bi-pointed artefacts of different shape and size were identified. Of interest are two pieces slim and lozengeshaped, with very sharp ends and a narrowing in the middle rare in the Iberian context (Figure 5(c) and Figure 5(d) and Figure S8). Chronostratigraphically they are linked to Level 3, of the Middle Bronze Age.

Typology of prehistoric bone tools tends to classify these bi-points objects as hooks (Averbouh, 2003; Averbouh \& Cleyet-Merle, 1995; Barandiarán, 2002; Cheyner, 1967; Voruz, 1987), thus giving rise to a debate parallel to that of the value of prehistoric fishing (Pickard \& Bonsáll, 2005) and its devices (Desse \& Desse, 1976; Mery et al., 2008; Olson et al., 2008; Parent, 1980).

The presence of straight hooks has been from the Aurignacian to the Magdalenian (Adán, 1997; Averbouh \& Cleyet-Merle, 1995). They are described in the Mesolithic and are associated with fish remains in Nerja (Malaga), Aizpea (Navarre), El Espertín (Leon) and Kobeaga (Bizkaia), the latter directly dated at $6945 \pm 65$ years BP (Aura et al., 2009; Barandiarán, 2002; Bernaldo de Quirós \& Neira, 2007-2008; López, 1998-2000). However, the most obvious parallels in shape and size with those from El Portalón can be drawn with Swiss stilts (Voruz, 1987) (Figure 6).

El Portalón has yielded no fish remains, perhaps due to its distance from the Arlanzón river, 4 kilometres away, and due to the fact that its course is not very rich in fishing resources. Moreover, the size of these hooks implies they would only be suitable for large-sized specimens. Given the intense work required to ensure symmetry, regular edges and polished surfaces, we believe that these artefacts were for display, perhaps for hanging clothing.

Whatever the case may be, what interests us is the connection between this region and Swiss territory. 


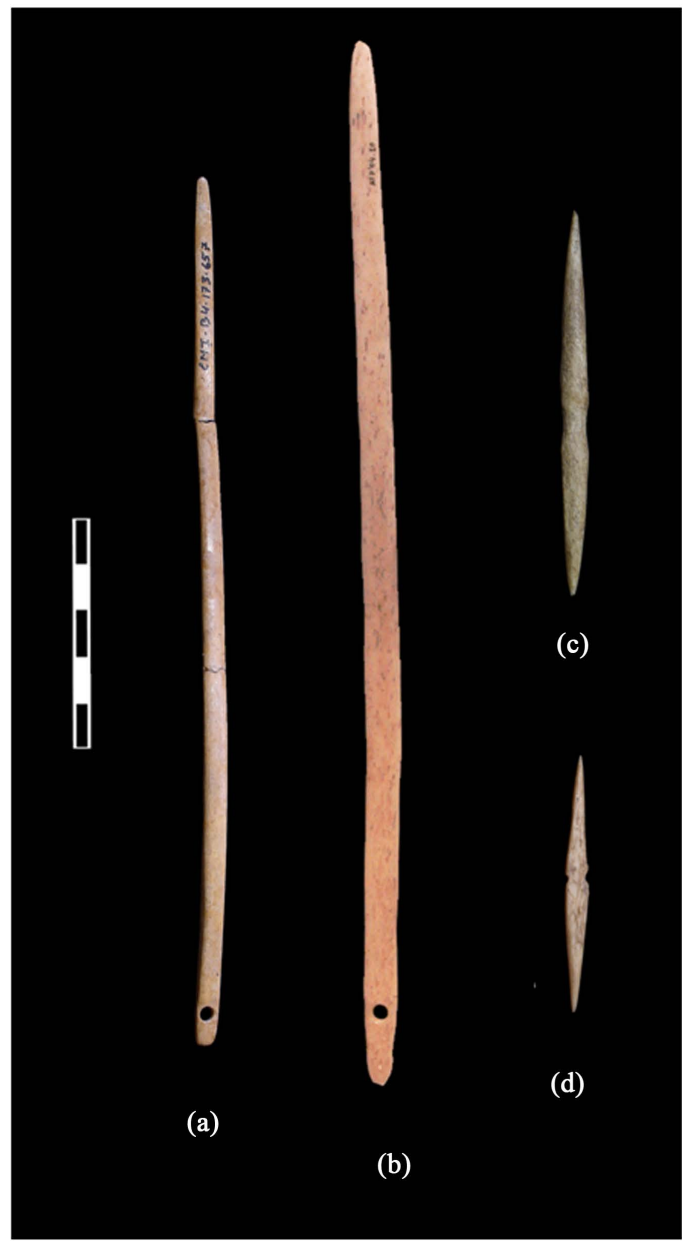

Figure 5. Two pins/needles ((a), (b)) and two bi-pointed/hook objects ((c), (d)) from El Portalón. The scale is $5 \mathrm{~cm}$.

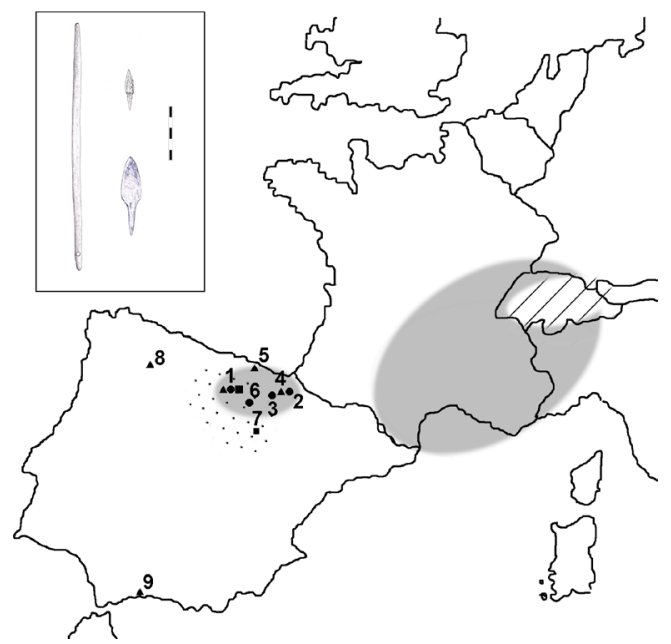

Figure 6. Western European regions and Spanish sites with needles (circles), bi-pointed objects (triangles) and arrowheads (squares) similar to those found in El Portalón. (1) El Portalón in Burgos; (2) Sakulo, (3) Tres Montes and (4) Aizpea in Navarra; (5) Kobeaga in Bizcaia; (6) La Atayuela in La Rioja; (7) Cueva Maja in Soria; (8) El Espertín in León; (9) Nerja in Málaga. 


\subsection{V-Perforated Buttons}

Twelve prismatic V-perforated buttons were recovered and the fact that the collection is restricted to the prismatic type is surprising because they are normally found in combination with other models of V-perforated buttons (hemispherical, conical, tortoiseshell and the durfort).

In Europe, prismatic models are the most common, with variations in sizes or in the number or arrangement of the perforation. Those in El Portalón (Figure 7 and Figures S9-S12) are the simplest and most common types. The model is concentrated in two areas: in the far eastern part of the Pyrenees and in the Quercy region of south west France. Either one of these regions would have inspired our samples and those of nearby settlements, such as of the dolmens of Las Arnillas, Zeontza and Sakulo, the shelters of Los Husos, Lóbrega Cave and Pico Ramos (Alday, 1987). It must surely be more than just a coincidence that one of those from El Portalón was made from ivory (Figure 7(e) and Figure S10), as was the case in nearby Covairada (Pastor, 1994), Pico Ramos (Zapata, 1995) and Sakulo (Apellániz, 1973). Parallels can be drawn with those found even further away towards the south and to the East (Figure 8).

Due to its unusual aspect, a last bone button from El Portalón points to the relationship of the site's inhabitants with those from other communities. Shaped like a spindle with a transversal perforation (Figure 7(f) and Figure S11), its identification as a button stems from its similarity in shape to the V-perforated tortoiseshell buttons. There is a similar object in the Iberian Peninsula in the burial site of Kobeaga (Bizkaia). El Portalón and Kobeaga likewise coincide in preserving similar bone tube necklace or bracelet beads (Alday, 1987). A similar piece was found in North West France, in the Petit Rocher site (Brétignolles, Loire) (Joussaume, 1981). Seen as a whole, it suggests a line of communication along the French Atlantic facade, the Basque depression and Northern Meseta, likewise recognisable in other grave goods. We also wonder if the Iberian examples should be linked to the French ones at La Baume de Gigny, the burial site of Collogne-les-Bevy and the mound at Vertempierre (Barge, 1982). They would point to a connection that tallies with that indicated by the pins and bi-points.

\subsection{Arrowheads}

The sample from El Portalón is the largest known collection of arrowheads in the Iberian Peninsula (Figure 9. Table S2 and Figure S13), and one of the most extensive in Europe. There are thirty specimens, but their lack of variety in shape is surprising (Alday et al., 2011) given the usual wide range of types known in the territory.

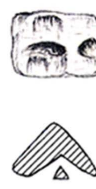

(a)

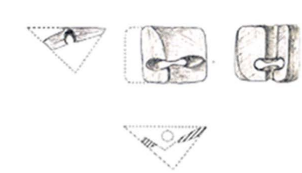

(b)

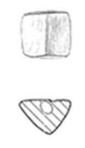

(c)

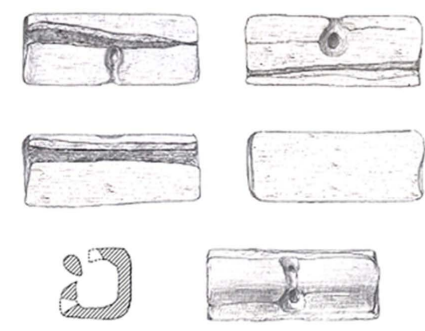

(d)

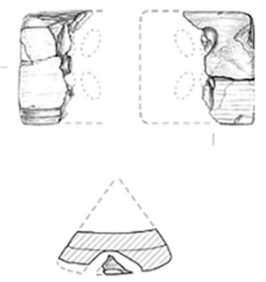

(e)

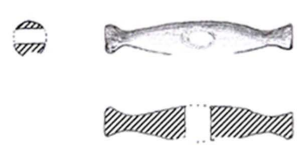

(f)

Figure 7. Prismatic V-perforated buttons made of bone ((a)-(d)) from El Portalón. Button made on ivory (e); tortoiseshell button (f). The scale is $5 \mathrm{~cm}$. 


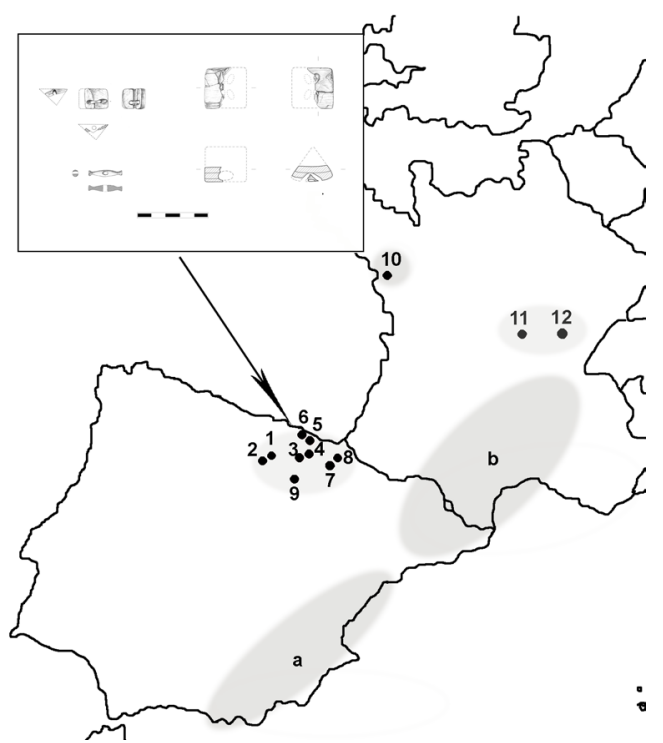

Figure 8. Western European regions and sites with Prismatic V-perforated buttons mentioned in the text. SPAIN: El Portalón (1) and Las Arnillas (2) in Burgos; Los Husos (3) and Covairada (4) in Alava; Kobeaga (5) and Pico Ramos (6) in Bizcaia; Zeontza (7) and Sakulo (8) in Navarra; Cueva Lóbrega (9) in La Rioja. FRANCE: Petit Rocher (10) in Brétignolles; Vertempierre (11) in Chagny; La Baume de Gigny (12) in de Barriera. (a) and (b): another regions with presence of V-perforated buttons.

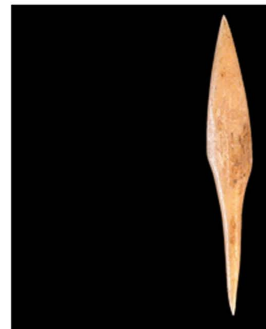

(a)

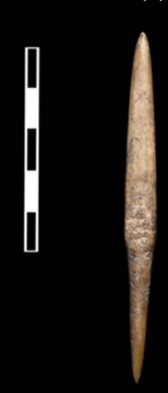

(d)

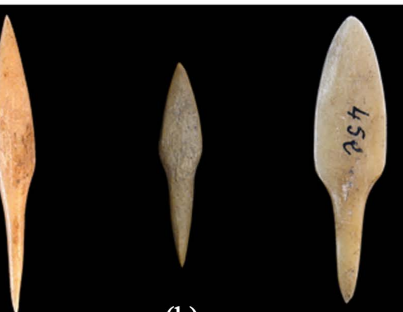

(b)

(c)

(e)

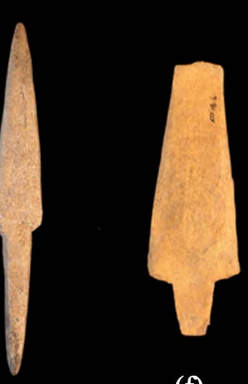

(f)

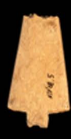

(g)

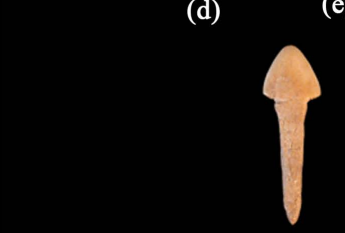

(h)

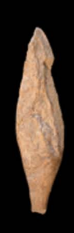

(i)

Figure 9. Basic types of arrowheads found at El Portalón. Lanceolate model with a slight differentiation of the stem ((a), (b)), palmela model (c), fusiform model with a well-differentiated stem ((d), (e)), triangular model with central stem ((f), (g)), unusual type with a long stem (h) and a specimen degenerated or incomplete (i). See Alday et al. (2011) for more details. Scale is $5 \mathrm{~cm}$. 
They are lanceolate models tapering gently towards the stem (Figure 9(a) and Figure 9(b) and Figures S14-S16), oval models with a slight differentiation of the stem (Figure 9(c) and Figure S17), fusiform models with a well-differentiated stem (Figure 9(d) and Figure 9(e) and Figure S18 and Figure S19), triangular ones with central stem (Figure 9(f) and Figure 9(g) and Figure S20(a)), an unusual one with a long stem (Figure 9(h) and Figure S20(b)) and another which has either degenerated or is incomplete (Figure 9(i)).

It is a homogeneous sample with slight differences in all probability produced locally. This would explain both, the absence of stemmed and winged arrowheads (usual in the sites of the region and in collections of lithic artefacts), as well as the specialisation in arrowheads with a spindle-shaped bodies and elongated stems. The marks left by cutting, polishing, rubbing, evening out and emptying the antler used to make the arrowheads are obvious, taking us back to the idea of local manufacture.

We attribute a symbolic rather than a practical function to these arrowheads. They do not seem suitable for hunting given the bluntness of their point and edges, although the hafting marks and the breaks in some of them could stem from their use. They are no substitute for those made out of flint. In these circumstances we consider them imitations of metal products, what would explain morphological coincidences such as that of one piece resembling "palmela" arrowhead (Figure 9(c)), or the similarity between our dominant model on bone and Kaiser's (2003) "long-stemmed" metallic one. Probably the absence in bone of the stemmed and winged metal model, which is not otherwise common in our territory, is a coincidence neither.

The first bone and metal arrowheads belong to the late Chalcolithic or the beginning of the Bronze Age. Both types are more frequently seen together in the Bronze Age, which is when the forms of our catalogue become widespread and are destined to prevail during the middle Bronze Age. These considerations tally well with El Portalón, given the levels yielding the materials and the radiocarbon dating for one of them $(3630 \pm 40$ years BP Beta 269493), identical to that for two arrowheads from Cueva Maja site, in Soria (3680 \pm 40 years BP GrN18066 and $3665 \pm 40$ years BP GrN-18067) (Figure 6 and Table S3).

The limited number of shapes of the arrowheads, their large number and the traces of use all lead to the hypothesis that El Portalón had its own production system, perhaps with a more social rather than practical purpose.

\subsection{Awl Made Out of Human Radius}

Two dozen awls have been inventoried from different levels, in most cases made of domestic sheep or goat bone and forming homogeneous collection but with some of them haphazard in their manufacture wile others very carefully made. One of them is made out of human radius and it is $7.6 \mathrm{~cm}$ long and $1.5 \mathrm{~cm}$ thick, with a straight base, annular section and polished surface (Figure 10 and Figure S21). Radiometric analysis of the specimen offers a value of $3900 \pm 40$ years BP (Beta-269494) (Table 1), in line with the Level 6 where it was found, and places us in the transition from the Chalcolithic to the Bronze Age period, slightly before the dated arrowhead mentioned above.

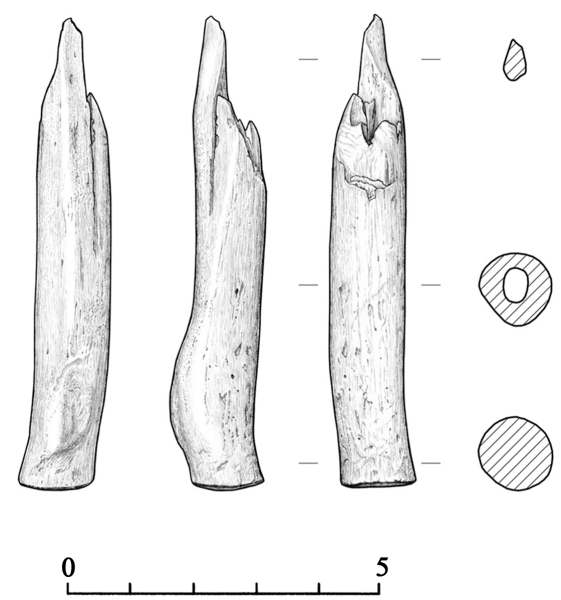

Figure 10. Awl made out of human radius from Level 6 of El Portalón (Chalcolithic-Bronze Age transition). 
Although this tool does not stand out for its morphology, size or manufacture, was made of human bone, and inevitably leads us to consider interpretations going beyond the merely functionality corresponding to its form. Of particularly interest is usually the extent of the link between the craftsman and users (and/or their group) and the identity of the individual to which the bone belongs. As Mujika (2007-2008) rightly states, these artefacts would have been invested with certain properties, as they are undoubtedly significant elements of the rich and complex funerary rituals carried out in the prehistoric Holocene. Nevertheless there are no much parallels with the awl from El Portalón and the connection with other European objects is questionable.

Two chronological precedents are found in two pieces from the North of the Iberian Peninsula. One is the spatula idol obtained from a human radius from the tomb of Los Zumacales (Valladolid) (Figure S22), the other the dagger, possibly obtained from a human tibia, from the Las Arnillas dolmen (Burgos) (Delibes \& De Paz, 2000). These latter authors recall the suggestive idea of circulating relics among the living in the complex burial rituals which emerge in middle Neolithic, or the equally interesting idea of their consideration as a trophy among bellicose societies.

Despite there are some artefacts made of human bones in European sites (Note S2) only on very rare occasions has the manipulation of human bones for making instruments been recorded (Figure 11). The intense work carried out on the bone-cuts and abrasions-prevents us, in most cases, from determining the origin of the raw material (Note S3). Nevertheless we could lucubrate about a tradition being more extended than previously thought, since, for example, among the objects from the Paradou Cave, we are able to identify a dagger made on the humerus of a child under three years of age instead of that of a sheep or goat, as had been assumed (see Figure 6, page 9 in Camps-Fabrer, 1990).

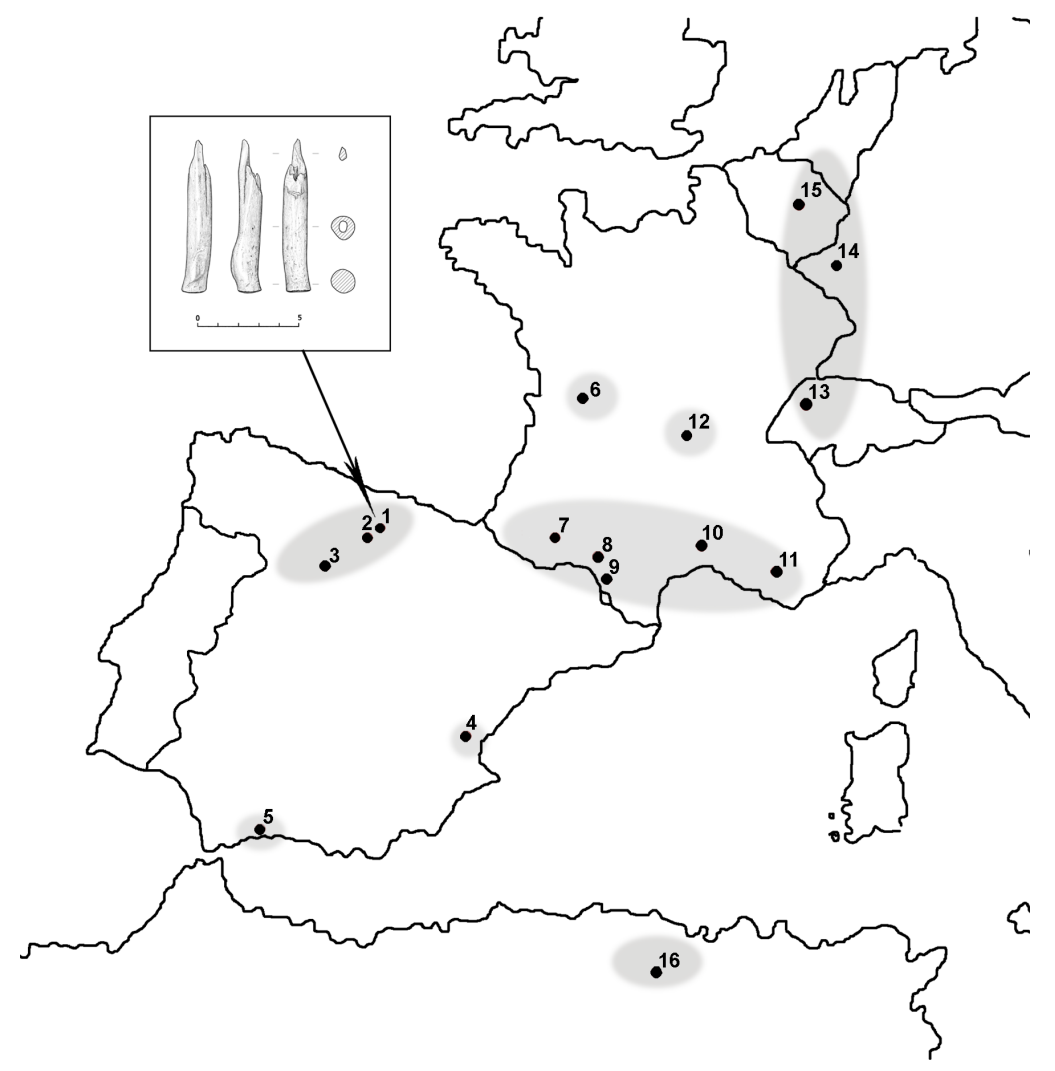

Figure 11. Main Western European regions and sites with bone tools made of human bones. SPAIN: El Portalón (1) and Las Arnillas (2) in Burgos; Los Zumacales (3) in Valladolid; Avenc dels Dos Forats (4) in Valencia; Nerja (5) in Málaga. FRANCE: Perrats (6) in Haute-Garonne; Spugo de Ganties (7) in Montespan; Grotte de Tutteil (8) in Monsegur; Grotte de Bedéilhac (9) in Ariege; Grotte de Paradou (10) in Gard; Frontbrégoua (11) in Var; Vertempierre (12) in Chagny. SWITZERLAND: Hauteville (13) in Fribourg. GERMANY: Herxheim (14) in Renania-Palatinado. BELGIUM: Grotte de Goyet (15) in Gesves. ALGERIA: Mechta-el-Arbi (16) in Qustantînah. 


\section{Discussion}

El Portalón of Cueva Mayor was occupied for several millennia during prehistory, and intensely so during the Bronze Age. The sedimentary characters of these levels appear to derive from the use of the shelter as a fold for livestock, with its stabling and cleaning phases (the Atapuerca Mountain Range, at $1000 \mathrm{~m}$ above sea level, is suitable for animal husbandry). Although this could have been the one of the site's main functions during the Bronze Age, its size, over $200 \mathrm{~m}^{2}$, allows for the development of other activities at the same time and at successive stages. Proof of the fact is the presence at level 7/8 of a Chalcolithic funerary tumulus (Figure 2 and Note S1).

Essential typological characteristics of selected pottery and bone tools production from the Neolithic to Bronze Age have been described as well as their similarities with materials from another Iberian and European sites. This comparison show us that the exchange networks active for this periods in prehistoric Europe and the traffic of these materials (mainly bone artifacts) is an intentional activity where economical, hierarchical and ideological interests are being expressed. Nevertheless in the 2000 years represented by the materials, the social and economic organization suffered important changes and the social capacities differed from each other, what make difficult to interpret completely the material exchanges from long distance.

As in most of the Iberian Peninsula, in this region, the Neolithic way of life started to take over at the end of the first half of the seventh millennium BP (Alday et al., 2009). By the last third of this millennium it was fully established on the coastal areas and in the interior of the Iberian Peninsula. The organisation of a sheepfold cave network for domestic livestock is one of the most patent strategies in the early Neolithic, and even more so in subsequent stages. El Portalón, El Mirador, Cueva Lóbrega, Los Husos I and II, to cite examples close to us, are large-sized shelters with a similar occupation and management programme. The livestock activities are complemented by other agricultural activities in open-air settlements, hunting in rock shelters and burial rites in diverse tombs. The organization of the territory is dynamic and integrating in concept, where inter- and supra-regional relations play an essential role. The Neolithization in the Iberian Peninsula then created complex scenes in which some external influences with different origins and directions were received and in which the distribution, interests and participation from the local groups were not uniform. These differences will be reflected in the pottery decorative tradition from Early Neolithic, the cardial type linked to Mediterranean and Southern and middle Portuguese Atlantic littoral, whereas the Boquique pottery was linked to inner Iberia, some Portuguese areas and to the Middle Ebro river Basin (Alday et al., 2011). Therefore, pottery making in the early Neolithic in the Iberian Peninsula reveals a stylistic compartmentalisation related to the interests of each group and with the relations they establish. If we consider pottery with printed cardial decoration an identity sign of the Mediterranean, then Boquique ornamentation should be that of the hinterland. This is the case of the Sierra de Atapuerca where its Boquique production, technically and stylistically homogeneous, points to local production but with a high degree of engagement with communities established in the Upper and Middle Ebro Basin, the Eastern part of the Bay of Biscay, the Meseta and part of Portugal. It is local production based on stylistic and ideological standards shared among several regions. The Boquique pottery from El Portalón, Galería del Sílex and El Mirador sites is the local recreation of a style linked to one of the organizational cores from the Iberian Neolithic.

Regional documentation for the middle and late Neolithic is very poor, except in the case of the burial system with active rituals in the Chalcolithic. Their funerary offerings provide the archaeologist with the materials to study the relationships between groups, as the circulation of semi-precious raw materials, bell-shaped pottery, ornamentation elements, metal tools, etc. Some previous works have establish links between the Northern Meseta territory and the French Atlantic facade, south east France and the Rhone valley (Delibes, 1983; Alday, 2001). Materials from El Portalón presented here offer similar readings, with the particularity of having been recovered from the domestic sphere instead from burials. They reinforce the thesis of prehistoric communities in permanent contact, with networks in which materials circulated as back up for economic, social and ideological transactions (detected also in El Portalón through the genetics of the livestock (Anderung et al., 2005). Bi-pointed needles and V-perforated buttons point to societies established in the far east of the Pyrenees, Rhone Valley and Switzerland; the buttons with a straight perforation take us there or to the French Atlantic facade. The bony pins and bi-pointed objects were probably sumptuary samples. They could be cloth and/or elaborated hairstyles supplements, with a value beyond the useful (exceeding their traditional cost). All of them were exchanged objects between the Meseta Castellana and Central Europe along these routes. We do not rule out the possibility of the connections actually going in other directions, but archaeological evidence published on the Iberian Peninsula 
fails to disclose this. The Sierra de Atapuerca is in the region where the Ebro and Duero Basins converge, and it is logical that even clearer connections will be found in the future. Some V-shaped perforated buttons were made by exotic material like ivory, and some pottery containers and metal tools from El Portalón are, when found in other sites, generally explained like exchanges of both, containers and contents, during feasts or ritual activities. Although we have focused on specific archaeological items in this work, the site's inventory provides other arguments to support the idea of a network of intergroup relations: a recipient with mixed bell-shaped decoration which is known to have circulated widely throughout Europe (Alday, 2001), an array of metal artefacts with prototypes widely spread over diverse areas as Fontbouisse-type daggers, compass-type daggers and pedunculate points, and flat axes and ornaments made out of sea shells which link the Burgos region with coastal sites.

Finally, regarding the awl made on a human radius, although there are some artefacts made of human bones in other European sites, their connection with that of El Portalón is questionable and interpretations going beyond the merely functionality corresponding to its form are not clear in this case.

\section{Conclusion}

The set of archaeological materials presented in this work belongs to two distinct cultural periods, the Early Neolithic on the one hand and the advanced Chalcolithic/Bronze Age on the other hand, the latter with presence of metal objects and both within the same cultural dynamics. The interval phase between these two periods, Middle-Late Neolithic and the pre bell-baker Chalcolithic, is only represented in the Portalón through complex funeral rituals.

In the Iberian Peninsula, after some pioneering events, the Neolithic begins by the two thirds of the seventh millennium cal BP and consolidates by the end of this millennium. It is within this last phase in which we contextualize the Neolithic remains from El Portalón. Although the evaluation of an isolated site by itself is useful and necessary, we cannot appreciate their full significance until we compare and put into context with other contemporary sites.

In this sense, El Portalón fits perfectly among the networks of Neolithic sites known for the upper basin of the Ebro River, showing that geographical barriers are not insurmountable when it is just a question of exploiting the environment holistically. This network, like others established on the Peninsula, informs us about the existence of a fully stabilized Neolithic at Iberian level, but developed in different "cultural circles", among which there are common cultural and material exchanges. The "cultural circle" of the Iberian region under study is identified by the Boquique ceramic decoration. In the vicinity of the Sierra de Atapuerca, this type of decoration has its own peculiarities, a family resemblance, in each of the sites where it is present. Thus, there is a deep bond with the Boquique circle, but local identity codes are developed: it is a local production within a regional framework.

As regards the materials from the Bronze Age, local productions combine with those of distant origins. In this line, both arrowheads and V-perforated buttons are part of a local manufacturing. The large sample of arrowheads from El Portalón is surprising however by its scarce variation, especially when such a kind of objects is very variable as a whole. Do the humans have these pieces in stock for internal use, or better yet, for external distribution given its social value? We remember here that this set of bone arrowheads seems to imitate their metal counterparts, much more difficult to obtain. The same is true of the V-perforated buttons. Their regional concentration fits well with a local production, even when they are reminiscent of European styles.

As for needles and bi-pointed objects, their use seems logical as decorative elements in clothing or hairstyles, although for the latter, its possible use as fishing hooks has also been indicated. In any case, both needles and bi-pointed objects are exotic products, with few parallels in the region and linked to European productions of the Rhine-Rhone valley, Switzerland and northern Italy. We think that in this case the idea of a movement of objects (not just the concepts) over long-distances is justified.

At this time in Europe the sociocultural context encourages supra-regional relationships (the Bell Beaker culture is a good example), and the great value of the metals and the need to locate outcrops are another incentives. Furthermore, it is highly suggestive to relate these cultural dynamics to the latest hypotheses derived from genetic studies, which highlight the importance of post-Neolithic demographic processes and the current characterization of the gene pool of recent Europeans (Brandt et al., 2013; Kind, 2010; Ricaut et al., 2012).

In this situation, where local and foreign products are mixed (as is the case of El Portalón), it is difficult to recognize whether the ideas, objects or persons (or a combination of the three) are involved. And we should also 
remember the complexity of the funerary world at this time (reusing dolmens, building burial mounds, digging graves and using caves). The complexity of these rituals and the richness and variety of grave goods help us to understand the awl made from a human bone founded at El Portalón, a symbolic element in a time of great social development.

In sum, El Portalón site at the Cueva Mayor complex is easier to understand if we examine it within the historical dynamics in which it develops rather than in its geographical setting. As we have argued here, the site is significant because it belongs to a network intertwined with different socio-economic realities.

\section{Acknowledgements}

We thank Marta Negro, director of the Burgos Museum, for the facilities offered for consulting different materials. We are deeply indebted to Laura Juez Aparicio for her help with the preparation of materials. Special appreciation to the Atapuerca team and our colleagues from the laboratory of Human Evolution at the University of Burgos Elena Santos, Laura Rodríguez and Rebeca García and from Centro UCM-ISCIII Eva Poza and María Cruz Ortega. Many thanks also to the many colleagues and students that since 2000 have made possible the excavation, restoration and inventory of the thousands of archaeological pieces recovered from El Portalón. M.A. GalindoPellicena has been supported by a grant from the Spanish Ministry of Science and Innovation (FPI reference BES-2007-15368; 2008-2011), by the Madrid City Council (lodging grant at The Residencia de Estudiantes 2008-2010) and nowadays from Fundación Atapuerca (postdoctoral grant). This research was financed by the Ministry of Science and Innovation via project $\mathrm{N}^{\circ}$ CGL2012-38434-C03-01 and project HAR-2011-26364. Excavations at the Atapuerca sites are financed by the Regional Government of Junta de Castilla y Leon and the Fundación Atapuerca.

\section{References}

Adán, G. (1997). De la caza al útil: La industria ósea del Tardiglaciar en Asturias. Oviedo: Consejería de Cultura, Principado de Asturias.

Alday, A. (1987). Los elementos de adorno personal y artes menores en los monumentos megalíticos del País Vasco meridional. Estudios de Arqueología Alavesa, 15, 103-353.

Alday, A. (2001). Vías de intercambio y promoción del campaniforme marítimo y mixto sobre el interior peninsular. Cuadernos de Arqueología de la Universidad de Navarra, 9, 111-174.

Alday, A., Carvalho, A. F., Cerrillo, E., González, A., Juez, L., Moral, S., \& Ortega, A. I. (2009). Reflejos del Neolítico Ibérico. La cerámica boquique: Caracteres, cronología y contexto. Barcelona: EDAR, Arqueología y Patrimonio.

Alday, A., Juez, L., Pérez-Romero, A., Adán, G., Santos, E., Galindo-Pellicena, M. A., Carretero, J. M., \& Arsuaga, J. L. (2011). La industria ósea de El Portalón de Cueva Mayor (Sierra de Atapuerca, Burgos). Biapuntados, puntas de flecha y agujas, morfología y funcionalidad. Munibe, 62, 227-249.

Anderung, C., Bouwman, A., Persson, P., Carretero, J. M., Ortega, A. I., Elburg, R., Smith, C., Arsuaga, J. L., Ellegren, H., \& Götherström, A. (2005). Prehistoric Contacts over the Straits of Gibraltar Indicated by Genetic Analysis of Iberian Bronze Age Cattle. Proceedings of the National Academic of Sciences, 102, 8431-8435. http://dx.doi.org/10.1073/pnas.0503396102

Andrés, T., García, M. L., \& Sesma, J. (2007). Tres Montes. Un sepulcro singular del III milenio en las Bárdenas Reales. En M. A. Hurtado (Coord.), La tierra te sea leve. Arqueología de la muerte en Navarra, Gobierno de Navarra (p. 262). Pamplona: Departamento de Cultura y Turismo, Institución Príncipe de Viana.

Apellániz, J. M. (1973). Corpus de materiales de las culturas prehistóricas con cerámica de la población de cavernas del País Vasco Meridional. Munibe, Suplemento l, 1-366.

Apellániz, J. M., \& Domingo, S. (1987). Estudios sobre Atapuerca (Burgos). II Los materiales de superficie del Santuario de la Galería del Sílex. Cuadernos de Arqueología de Deusto, 10, 1-342.

Arsuaga, J. L., Bermúdez de Castro, J. M., \& Carbonell, E. (Eds.) (1997). The Sima de los Huesos Hominid Site. Journal of Human Evolution, Special Issue 33, 105-421. http://dx.doi.org/10.1006/jhev.1997.0169

Aura, J. E., Jordá, J. F., Pérez, M., Morales, J. V., García, O., González-Tablas, F. J., \& Avezuela, B. (2009). Epipaleolítico y Mesolítico en Andalucía Oriental. Primeras notas a partir de los datos de la Cueva de Nerja (Málaga, España). El Mesolítico geométrico en la Península Ibérica, Monografías arqueológicas 44, 343-360. 
Averbouh, A. (2003). Les petits éléments droits à double pointe. In J. Clottes, \& H. Delporte (Eds.), La grotte de la Vache (Ariège). Fouilles Romain Robert. I. Les occupations du Magdalénien (pp. 353-356). Paris: Éditions du CTHS.

Averbouh, A., \& Cleyet-Merle, J. J. (1995). Fiches hamençons. In H. Camps-Fabrer (Ed.), Fiches Typologiques de l'industrie osseuse préhistorique. Cahier VII. Eléments barbéles et apparentés (pp. 83-99). Treignes: Editions du Cédarc.

Barandiarán, I. (1967). El Paleomesolítico del Pirineo Occidental. Monografías Arqueológicas III. Zaragoza.

Barandiarán, I. (1978). La Atalayuela: Fosa de inhumación colectiva del Eneolítico en el Ebro Medio. Príncipe de Viana, 152-153, 381-488.

Barandiarán, I. (2002). La industria ósea: Elaboraciones sobre hueso, asta y concha. In: A. Cava, \& I. Barandiarán (coords), Cazadores-recolectores en el Pirineo navarro: Sitio de Aizpea entre 8000 y 6000 años antes de ahora (pp. 179-212).

Barge, H. (1982). Les parures du Néolithique ancien au début de l'âge des métaux en Languedoc. París: CNRS.

Bermúdez de Castro, J. M., Carbonell, E., \& Arsuaga, J. L. (Eds.) (1999). Gran Dolina Site: TD6 Aurora Stratum (Burgos, Spain). Journal of Human Evolution, 37, 309-700.

Bernaldo de Quirós, F., \& Neira, A. (2007-2008). Una pieza excepcional del Mesolítico cantábrico: El anzuelo de la cueva de "El Espertín" (Cuenabres, Burón, León). Veleia, 24-25, 571-579.

Brandt, G., Haak, W., Adler, C. J., Roth, C., Szécsényi-Nagy, A., Karimnia, S., et al. (2013). Ancient DNA Reveals Key Stages in the Formation of Central European Mitochondrial Genetic. Science, 342, 257-261. http://dx.doi.org/10.1126/science.1241844

Camps-Fabrer, H. (1990). Fiche poinçons sur tibia d'Ovis/Capra. In H. Camps-Fabrer, D. Ramseyet, \& D. Stordeur, (dir.), Fiches typologiques de l'industrie osseuse préhistorique, cahier III: Poinçons, pointes, aiguilles, poignards, fiche $n^{\circ} 2$. Aix-en-Provence: Éd. de l'Université de Provence.

Camps-Fabrer, H., Ramseyer, D., Stordeur, D., Buisson, D., \& Provenzano, N. (1990). Fiches typologiques de l'industrie osseuse préhistorique, cahier III. Poinçons, pointes, poignards, aiguilles. Aix-en-Provence: Éd. de l'Université de Provence.

Carretero, J. M., Ortega, A. I., Juez, L., Pérez-González, A., Arsuaga, J. L., Pérez-Martínez, R., \& Ortega, M. C. (2008). A Late Pleistocene-Early Holocene archaeological sequence of Portalón de Cueva Mayor (Sierra de Atapuerca, Burgos, Spain). Munibe, 59, 67-80.

Cheyner, A. (1967). Comment vivait I'homme des Cavernes a l'Age du Renne. Paris: Ed. Robert Armoux.

Delibes, G. (1983). El País Vasco, encrucijada cultural en el inicio del Bronce Antiguo (siglo XVIII a. de J.C.). Varia, II, 131-164.

Delibes, G., \& De Paz Fernández, F. J. (2000). Ídolo-espátula sobre radio humano en el ajuar de un sepulcro megalítico de la Meseta. SPAL, 9, 341-350. http://dx.doi.org/10.12795/spal.2000.i9.18

Desse, G., \& Desse, J. (1976). La pêche. In H. de Lumley (Ed.), La Préhistoire Française (pp. 697-702). Paris: CNRS.

Joussaume, R. (1981). Le Néolithique de l'Aunis et du Poitou Occidental dans son cadre atlantique (pp. 620). Rennes: Travaux du laboratoire d'Anthropologie-Préhistoire-Protohistoire et Quaternaire Armoricain.

Kaiser, J. M. (2003). Puntas de flecha de la Edad del Bronce en la Península Ibérica. Complutum, 14, 73-106.

Kind, C.-J. (2010). Diversity at the Transition-A View from the Mesolithic. In D. Gronenborn, \& J. Petrasch (Eds.), Die Neolithisierung Mitteleuropas: Internationale Tagung, the Spread of the Neolithic to Central Europe (pp. 449-460). Mainz: Verlag des Römisch-Germanischen Zentralmuseums.

López, J. C. (1998-2000). El yacimiento prehistórico de la cueva de Kobeaga II (Ispaster, Bizkaia): Cazadores-recolectores en el País Vasco atlántico durante el VIII y VII milenio b.p. Illunzar, 4, 83-162.

Mery, S., Charpentier, V., \& Beech, B. M. (2008). First Evidence of Shell fish-Hook Technology in the Gulf. Arabian Archeology and Epigraphy, 19, 15-21. http://dx.doi.org/10.1111/j.1600-0471.2007.00289.x

Mujika, J. A. (2007-2008). La gestión de la materia prima ósea en la fabricación de objetos durante la prehistoria. Veleia, 24-25, 531-568.

Olson, C., Limburg, K., \& Söderblom, C. (2008). Stone Age Fish-Hooks-How Were They Dimensioned? Morphologie, Strength Test, and Breakage Pattern of Neolithic Bone Fish Hooks from Ajvide, Gotland, Sweden. Journal of Archaeological Science, 35, 2813-2823. http://dx.doi.org/10.1016/j.jas.2008.05.009

Ortega, A. I., Juez, L., Carretero, J. M., Ortega, M. C., Arsuaga, J. L., \& Pérez-González, A. (2008). El neolítico en la nueva secuencia estratigráfica del yacimiento del Portalón de Cueva Mayor (Sierra de Atapuerca, Burgos). Actas del IV Congreso del Neolítico Peninsular, Tomo I, 27-30 November 2008, 221-229.

Parent, R. (1980). Réflexions sur de présumés modes de pêche préhistoriques. Cahiers Archéologiques de Picardie, 7, 43-47. http://dx.doi.org/10.3406/pica.1980.1308

Pastor, B. (1994). El trabajo del marfil durante el Bronce Final y la Edad del Hierro en la mitad norte peninsular. ${ }^{\circ}$ Congreso de Arqueología Peninsular. Actas III. Trabalhos de Antropologia e Etnologia, 34, 191-207. 
Pickard, C., \& Bonsall, C. (2005). Deep-Sea Fishing in the European Mesolithic: Factor Fantasy? European Journal of Archaeology, 7, 273-290. http://dx.doi.org/10.1177/1461957104056504

Ricaut, F., Cox, M., Lacan, M., Keyser, C., Duranthon, F., Ludes, B., et al. (2012). A Time Series of Prehistoric Mitochondrial DNA Reveals Western European Genetic Diversity Was Largely Established by the Bronze Age. Advances in Anthropology, 2, 14-23. http://dx.doi.org/10.4236/aa.2012.21002

Rodanés, J. M. (1987). La industria ósea prehistórica en el Valle del Ebro. Diputación General de Aragón.

Vergés, J. M., Allué, E., Angeluccí, D. E., Burjachs, F., Carrancho, A., Cebriá, A., Expósito, I., Fontanals, M., Moral, S., Rodríguez, A., \& Vaquero, M. (2008). Los niveles neolíticos de la cueva del Mirador (Sierra de Atapuerca Burgos): Nuevos datos sobre la implantación y el desarrollo de la economía agropecuaria en la submeseta norte. Actas del IV congreso del Neolítico Peninsular, Tomo I, 27-30 November 2008, MARQ. Museo Arqueológico de Alicante. Diputación de Alicante, 418-427.

Voruz, J. L. (1987). Typologie analytique d'industries osseusses néolithiques. L'industrie en os et bois de cervidé durant Ie Néolithique et l'Age des Metaux II (pp. 77-105). Paris: C.N.R.S.

Zapata, L. (1995). La excavación del depósito sepulcral calcolítico de la cueva Pico Ramos (Muskiz, Bizkaia). La industria ósea y los elementos de adorno. Munibe, 47, 35-90. 


\section{Supplementary Information}

\section{The Site}

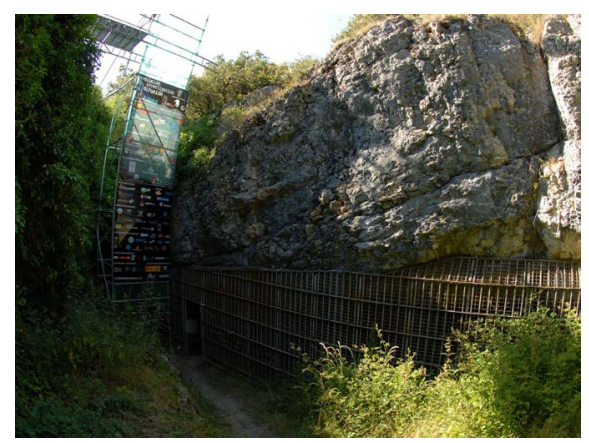

Figure S1. Present main entrance to Cueva Mayor-Cueva del Silo karst system.

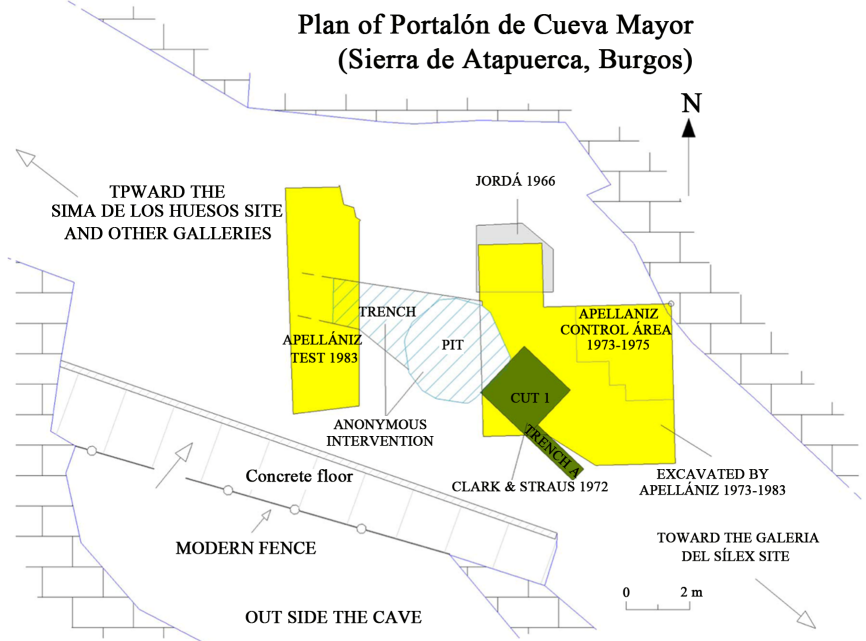

Figure S2. Portalón scaled-down plan showing the different excavations areas as well as the anonymous intervention that removed part of the site (trench and pit). Francisco Jordá (University of Salamanca), Geoffrey A. Clark (University of Arizona), Lawrence G. Straus (University of New Mexico), Juan María Apellániz (University of Deusto).

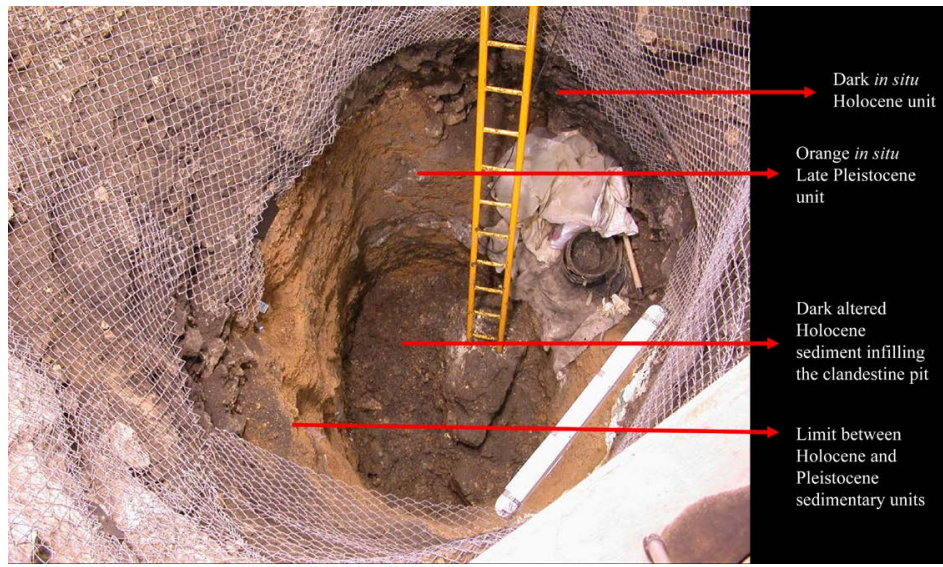

Figure S3. Clandestine excavation (pit) in the central part of El Portalón carried out by unknown individuals (see Figure S2). From 2001 to 2006 we excavated the disturbed fill of the clandestine excavation, among which we had found some significant archaeological materials although out of their original context. The complete excavation of the clandestine pit revealed a deep stratigraphic sequence that was unrealized until now. 


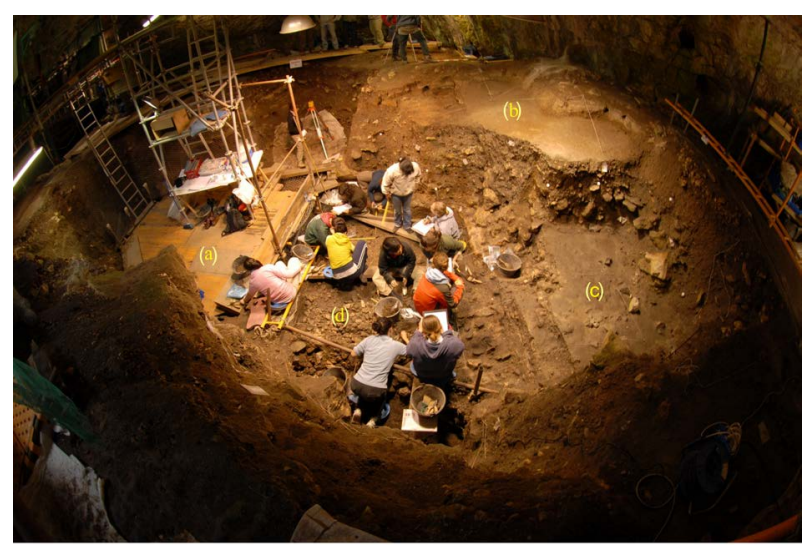

Figure S4. General view of El Portalón excavation area. (a) clandestine pit; (b) Apellániz control area in Figure S2; (c) area excavated by Apellániz; (d) actual excavation during 2008 field season.

Table S1. All available radiometric dates from El Portalón.

\begin{tabular}{|c|c|c|c|c|c|c|}
\hline Level & Sample & Section & Material & Analysis & Age in years BP & Lab. No. \\
\hline 1 & I. 1 & NORTH & Bone & AMS & $1000 \pm 40$ & Beta-224081 \\
\hline 1 & I. 2 & SOUTH & Charcoal & AMS & $1980 \pm 40$ & Beta-212187 \\
\hline 1 & I. 3 & SOUTH & Charcoal & Radiometric & $2040 \pm 100$ & Beta-153359 \\
\hline 1 & I. 4 & SOUTH & Charcoal & AMS & $2050 \pm 40$ & Beta-161192 \\
\hline$? ?$ & АТР 00-9 & Disturbed & bone awl & AMS & $1030 \pm 40$ & Beta-269492 \\
\hline $1 / 2$ & I/II.1 & NORTH & Charcoal & AMS & $2490 \pm 40$ & Beta-201763 \\
\hline 2 & II.1 & SOUTH & Bone & AMS & $2490 \pm 40$ & Beta-222335 \\
\hline 2 & II. 2 & SOUTH & Charcoal & AMS & $2510 \pm 40$ & Beta-197388 \\
\hline 3 & III.1 & SOUTH & Organic sediment & Radiometric & $3330 \pm 70$ & Beta- 153360 \\
\hline 3 & III. 2 & SOUTH & Bone & AMS & $3560 \pm 50$ & Beta-222336 \\
\hline $3 / 4$ & III/IV.1 & NORTH & Charcoal & AMS & $3330 \pm 60$ & Beta-201761 \\
\hline $3 / 4$ & III/IV.2 & NORTH & Charcoal & AMS & $3560 \pm 40$ & Beta-184840 \\
\hline 4 & IV.1 & SOUTH & Charcoal & AMS & $3490 \pm 40$ & Beta-212188 \\
\hline 4 & IV.2 & SOUTH & Charcoal & AMS & $3680 \pm 40$ & Beta-153361 \\
\hline 4 & ATP 02-2 & Disturbed & Arrowhead & AMS & $3630 \pm 40$ & Beta-269493 \\
\hline 5 & V.2 & SOUTH & Tooth & AMS & $3670 \pm 40$ & Beta-224079 \\
\hline 5 & V.3 & SOUTH & Charcoal & Radiometric & $3700 \pm 70$ & Beta-184843 \\
\hline 5 & V.4 & NORTH & Charcoal & AMS & $3740 \pm 40$ & Beta-184839 \\
\hline 5 & V.5 & NORTH & Tooth & AMS & $3760 \pm 40$ & Beta-184838 \\
\hline 6 & VI.1 & SOUTH & Organic sediment & Radiometric & $3910 \pm 70$ & Beta-153363 \\
\hline 6 & ATP 08-8 & In situ & Awl on human radius & AMS & $3900 \pm 70$ & Beta-269494 \\
\hline $7 / 8$ & VIII.1 & SOUTH & Tooth & AMS & $4440 \pm 50$ & Beta-197389 \\
\hline 9 & IX.1 & SOUTH & Charcoal & AMS & $4990 \pm 40$ & Beta-184841 \\
\hline 9 & IX.2 & SOUTH & Charcoal & AMS & $5230 \pm 40$ & Beta-184842 \\
\hline 9 & IX.3 & NORTH & Charcoal & Radiometric & $6070 \pm 110$ & Beta-201762 \\
\hline 9 & IX.4 & NORTH & Bones & AMS & $6100 \pm 50$ & Beta-222339 \\
\hline 9 & IX.5 & NORTH & Charcoal & AMS & $7790 \pm 40$ & Beta-197387 \\
\hline 9 & IX.6 & SOUTH & Organic sediment & AMS & $6270 \pm 40$ & Beta-222340 \\
\hline 10 & X-P1.2 & SOUTH & Bone & AMS & $16980 \pm 80$ & Beta-209452 \\
\hline
\end{tabular}




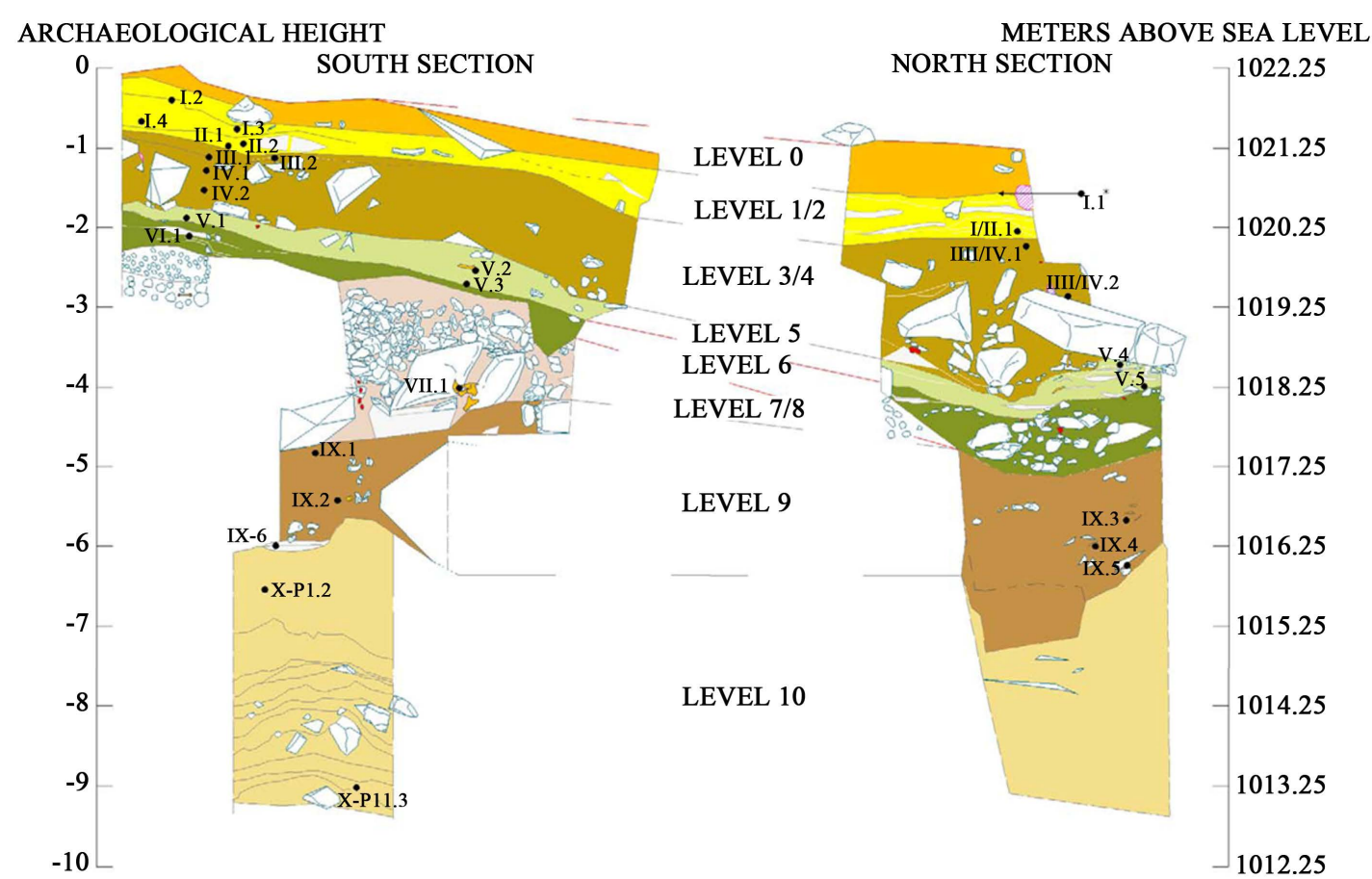

Figure S5. Stratigraphical sketch of the North and South profiles of El Portalón. Black dots indicate the position of the samples for radiocarbon dating labelled as in Table 1 and Table S1. Asterisk (*) indicates a sample taken in the East profile and projected on the North section.

Note S1: The stratigraphical cultural sequence of el portalón (see Carretero et al. 2008 for more details)

Level 0 (Medieval). It corresponds to an irregular alteration of the first 15 to $68 \mathrm{~cm}$ of the top of the sequence and is composed of brown deposits with organic materials, charcoal, faunal remains, and ceramics.

Level 1 (Roman). Is an ashy layer with dispersed charcoal in dark grey clays, with small limestone clasts, and a maximum thickness of $40 \mathrm{~cm}$. Artifacts include ceramics and Roman terra sigillata.

Level 2 (Iron Age I). It consists of organic sediments of anthropogenic origin with abundant ash and dark clay that reach a maximum depth of $30 \mathrm{~cm}$. Hand made ceramics were recovered in this level (Clark, 1979).

Level 3 (Middle Bronze Age). It consists of a thin collection of dark sandy-clayey layers of some $16 \mathrm{~cm}$ in thickness. Organic material is abundant with numerous charcoal grains, fragments of hand-made ceramics, and domestic and wild fauna remains (Clark, 1979).

Level 4 (Early Bronze Age). It corresponds to a homogeneous layer of sandy-clayey of between

70 and $150 \mathrm{~cm}$ in thickness, increasing in depth toward the west or interior of Cueva Mayor. This level is rich in organic and charcoal material, with numerous stones and large limestone blocks originating from collapse of the cave. Abundant hand-made potsherds, lithics, bone industry and fauna remains are found in this level.

Level 5 (Early Bronze Age). It consists of sandy-clayey of grayish tones with an average thickness of about $35 \mathrm{~cm}$ and abundant charcoal and ash in its base. There are abundant sherds and domestic faunal remains. The excavation of J.M. Apellániz (Figure S2) ended in this level documenting one bell beaker sherd typical of the Early Bronze Age.

Level 6 (Bronze Age-Chalcolithic Transition). It consists a $30-35 \mathrm{~cm}$ of sandy-clayey with abundant organic material and charcoal with grayish color. A lens of ash has been documented $22 \mathrm{~cm}$ towards its base lenses of ash are documented. Sherds and animal bone were recovered from this level. The excavation of J.A. Clark and L.G. Straus (Figure S2) terminated in this unit.

Level 7/8 (Chalcolithic). It consists of angular and subangular limestone rocks $(15-20 \mathrm{~cm})$ without matrix that increase in size within depth. In the base of this level large limestone blocks appear, among which two flat stones of around $70 \mathrm{~cm}$ high by $60 \mathrm{~cm}$ wide stand out. Abundant human remains have been documented at this level, such as pottery and fauna remains. The remains of a large ceramic vessel with decorations of pellets, a copper awl and the presence of two goats in anatomical articulation on the two large flat stones at the base, point 
to the use of this cavity during the Chalcolithic for mortuary purpose. As a whole the level may be a funerary tumulus or burial mound. The level reaches a maximum thickness of $200 \mathrm{~cm}$ in the South profile, while thinning toward the North (Figure 2 and Figure S5).

Level 9 (Neolithic and Mesolithic). Is the bottom part of the Holocene sequence and is composed of a very homogenous layer of anthropic origin characterized by clayey-sandy deposits with blackish tones, with numerous organic material and rich in charcoal fragments. In this unit sub- angular limestone lasts and small calcareous blocks $(10-20 \mathrm{~cm})$ are observed, together with some rounded quartzite lasts. It has an average thickness of $125 \mathrm{~cm}$ in its southern profile that thickens toward the North to $170 \mathrm{~cm}$. The base of this large layer is broken by an intrusive silo with a depth of about $75-80 \mathrm{~cm}$ and a diameter of $130 \mathrm{~cm}$ that has in turn affected the lower levels $9 \mathrm{a}$ and 10 . We have distinguished two very different chronological zones within this level. Most of level 9 corresponds clearly to Neolithic with handmade sherds ceramic, macrofauna remains, lithics and bone tools. A bone awl of clearly Neolithic typology was recovered in situ in the North profile beside a charcoal with a Neolithic chronology. And at the base of the level we have detected a Mesolithic occupation of the site, without finding any handmade sherds ceramic in this layer. The dates (Table S1) indicate a large occupation situated fully within the Neolithic (4990 \pm 40 to $6100 \pm 50$ and $6270 \pm 4$ years BP), and another during the Mesolithic (7790 \pm 40 years BP) but with a temporal hiatus of 1720 years between both occupations.

Level 9a (Holocene-Pleistocene Transition). It consists of a small layer of bat guano 5 to $8 \mathrm{~cm}$ thick characterized by sterile muddy-sand. It represents a transition between the Holocene (Levels 0 to 9 ) and Pleistocene (Level 10).

Level 10 (Upper Pleistocene). Is the deepest sedimentary unit and it is in turn divided into 12 sub-levels from $\mathrm{P} 1$ to P12. It is characterized by an alternation of angular limestone clasts of more than $1 \mathrm{~cm}$ originating from debris flow, containing a brownish muddy sandy-clay matrix inserted between levels of clays and sandy-clays which show a near absence of clasts. This level is more than $360 \mathrm{~cm}$ thick and has abundant microfaunal remains along with a small amount of macrofauna. Four small blades of flint (BP1G type) were recovered in the P8 sub-level. There is a date of $16980 \pm 80 \mathrm{BP}$ for P1 sub-level (60 cm deep) and another one of 30,300 $\pm 190 \mathrm{BP}$ for P11 sub-level (335 cm deep) (Table S1).

\section{Pottery}

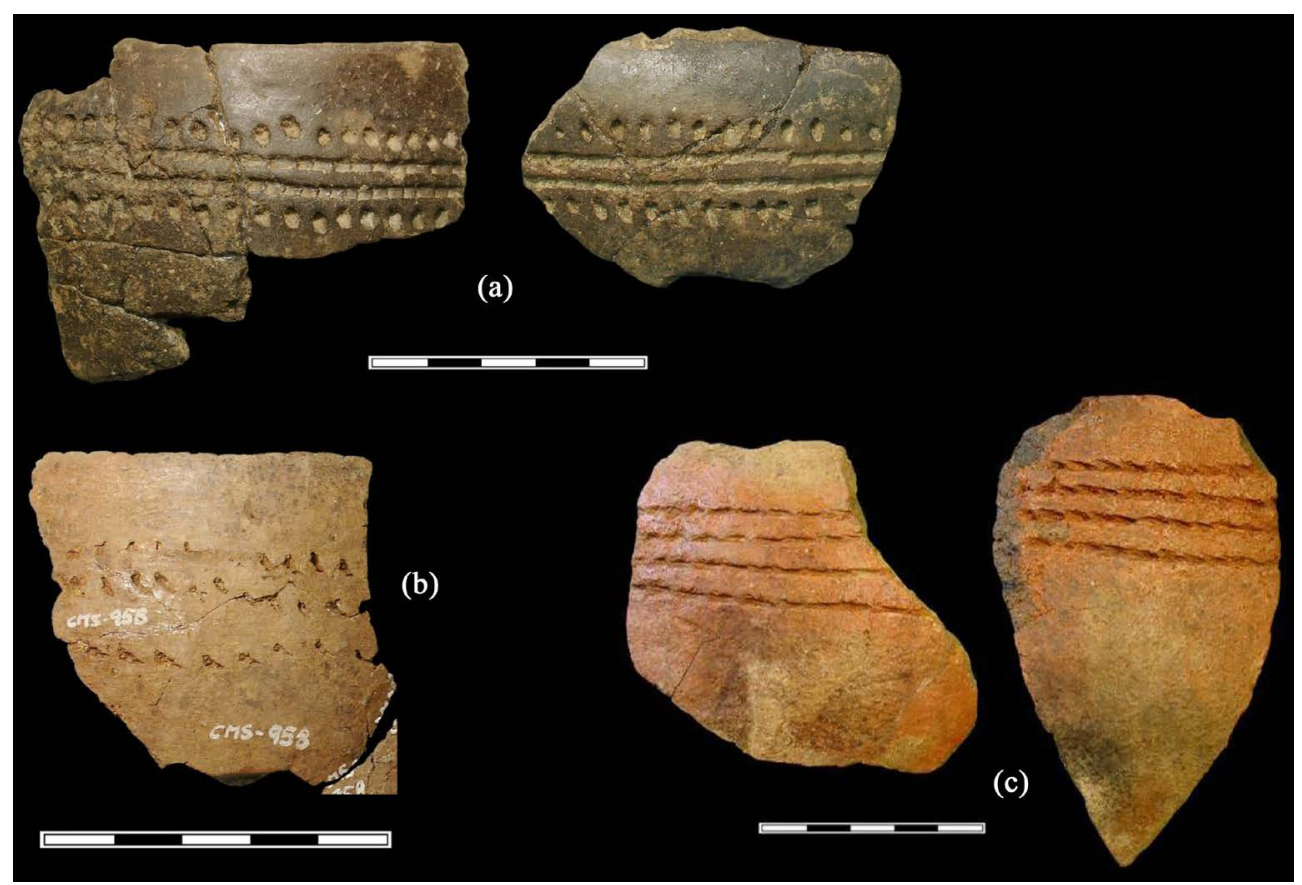

Figure S6. Examples of Neolithic pottery with Boquique decoration from Galería del Sílex (Cueva Mayor, Atapuerca). (a) Two pseudoboquique horizontal lines framed by circular prints; (b) Three boquique horizontal lines; (c) Four boquique horizontal lines. Scales are $5 \mathrm{~cm}$. 


\section{Bone Industry}

Table S2. Bone industry from E1 Portalón by categories and types.

\begin{tabular}{|c|c|c|c|}
\hline Category & Type & $\mathbf{N}$ & Total \\
\hline \multirow{5}{*}{ Pointed objects } & Awls & 85 & \multirow{5}{*}{126} \\
\hline & Arrowheads & 27 & \\
\hline & & & \\
\hline & Bipointed objects & 6 & \\
\hline & Pins/Needles & 8 & \\
\hline \multirow{7}{*}{ Perforated objects } & Buttons & 15 & \multirow{7}{*}{73} \\
\hline & Beads & 35 & \\
\hline & Rings & 1 & \\
\hline & & & \\
\hline & Pendants & 5 & \\
\hline & Tubes & 2 & \\
\hline & Shells & 18 & \\
\hline Beveled objects & & 1 & 1 \\
\hline \multirow[b]{2}{*}{ Blunt objects } & Spatulae & 8 & \multirow[b]{2}{*}{9} \\
\hline & Compressors & 1 & \\
\hline Denticulated objects & & 2 & 2 \\
\hline \multirow[t]{2}{*}{ Undetermined objects } & Indeterminate & 22 & 22 \\
\hline & & & 233 \\
\hline
\end{tabular}

Table S3. Dated bone industry from El Portalón and another Spanish sites mentioned in the text.

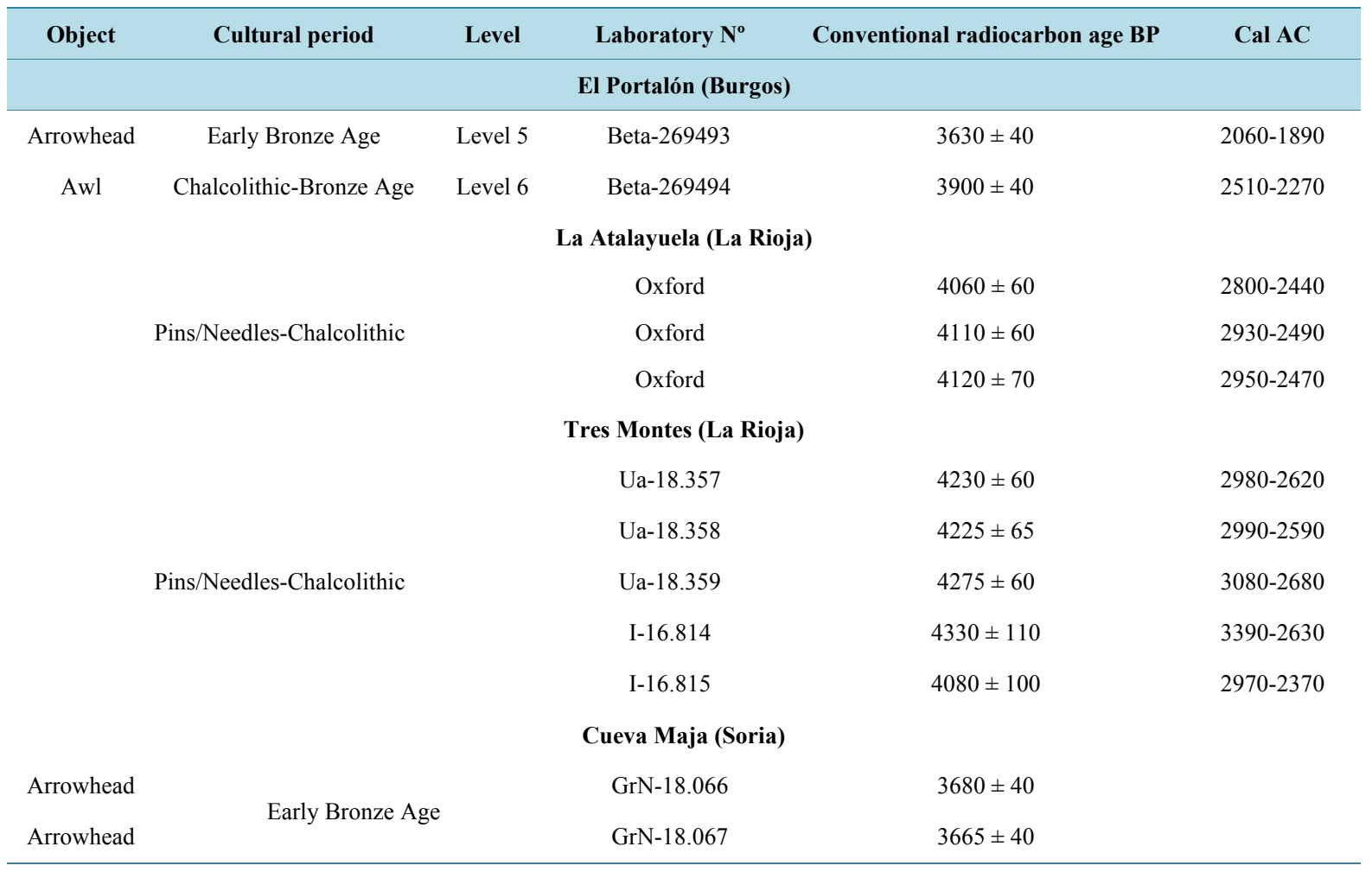




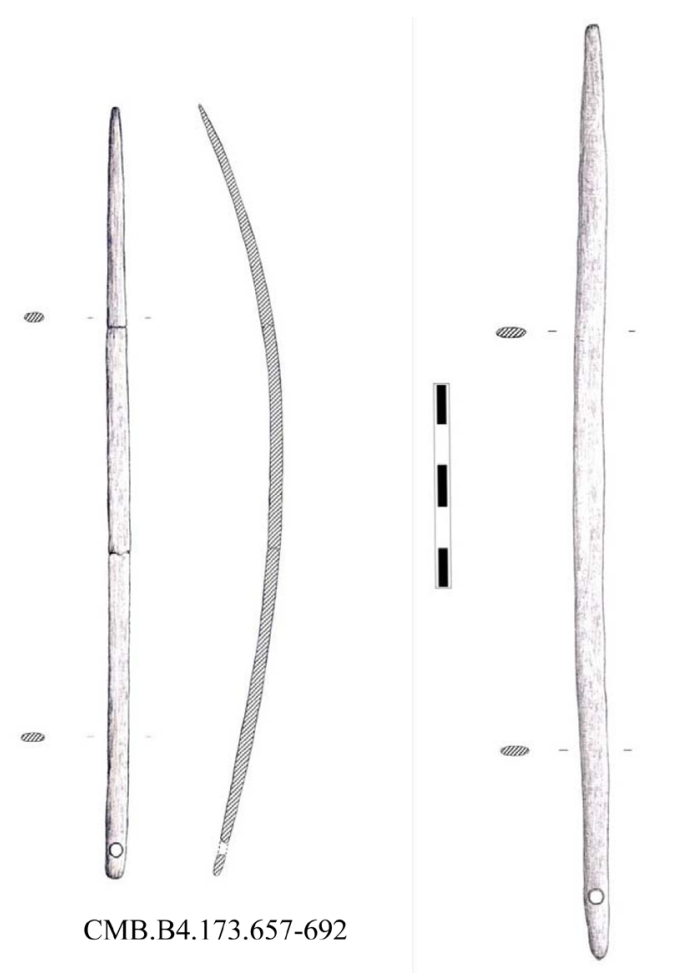

(a)

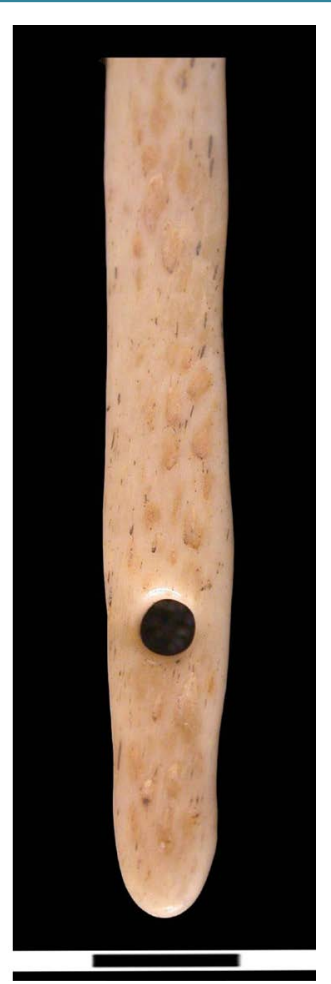

(c)

Figure S7. ((a), (b)) = technical drawings of the two needles represented in Figure 5 from El Portalón (23 and $29 \mathrm{~cm}$ long respectively and $0.8 \mathrm{~cm}$ wide and $0.25 \mathrm{~cm}$ thick both) made out long size animal rib; (c) Detail of the perforation of ATP 04-10 where it can be seen the wear left by the passage of the string. Scales in $\mathrm{cm}$.
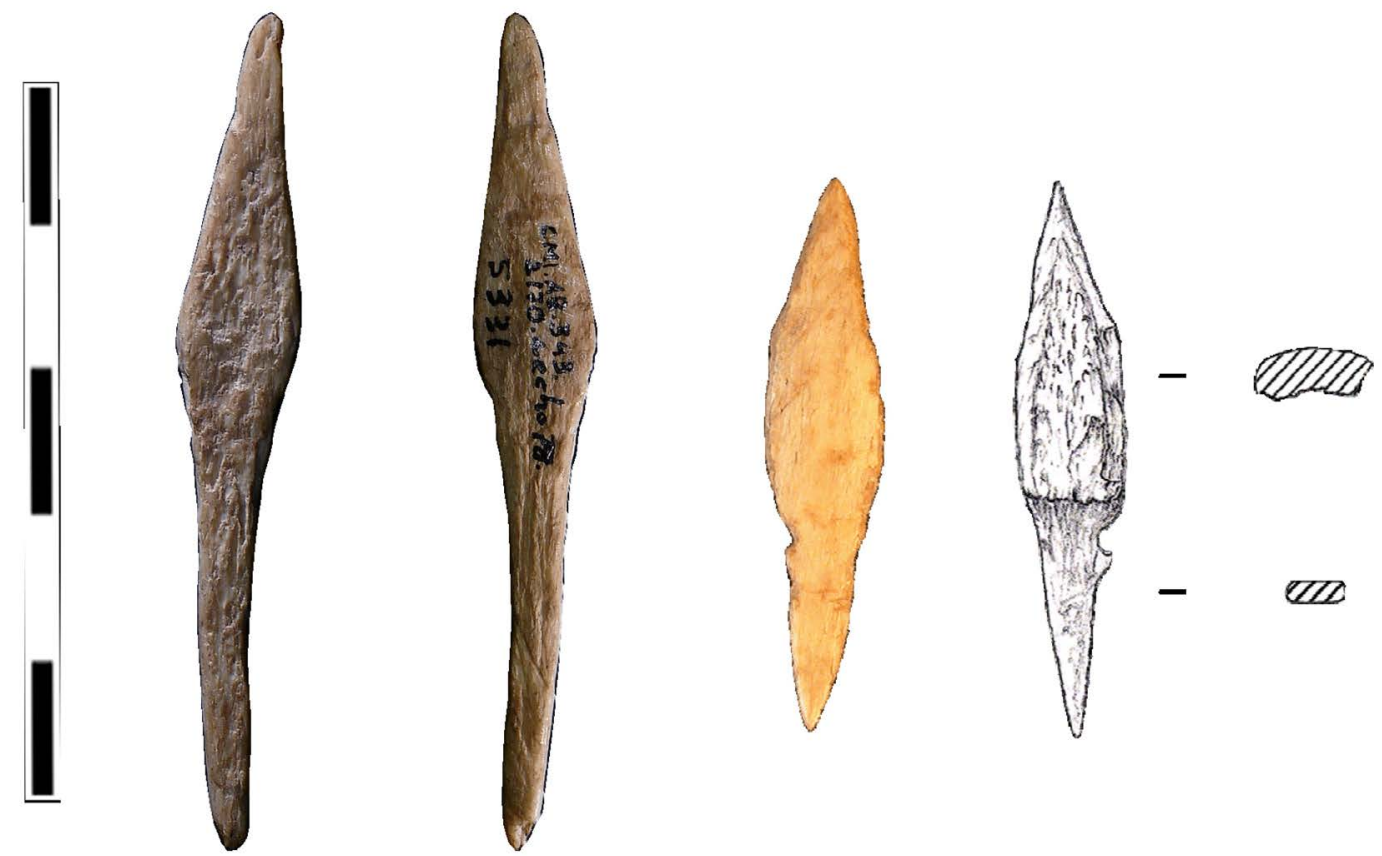

(a)

(b)

Figure S8. Two bi-pointed objects from El Portalón interpreted as straight hooks for fishing. See also Figure 5. The larger (a) is $85 \mathrm{~mm}$ long and the smaller, CMI.A8.343.2170; (b) is $56 \mathrm{~mm}$ long. Scale is $5 \mathrm{~cm}$, ATP 03-4. 


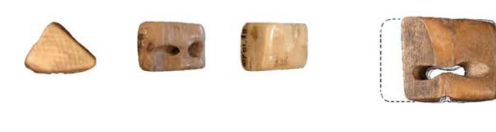

(a)
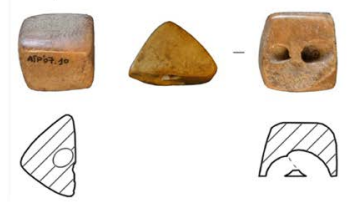

(d)

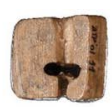

(b)

(c)

\section{- - -}

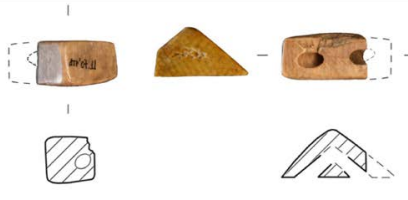

(e)

Figure S9. Prismatic V-perforated buttons from El Portalón; (a) and (b) also represented in Figure 7(a) and Figure 7(b) respectively. Scale is $5 \mathrm{~cm}$. (a) ATP 01-10; (b) ATP 01- 11; (c) CM 5380; (d) ATP 07-10; (e) ATP 07-11.

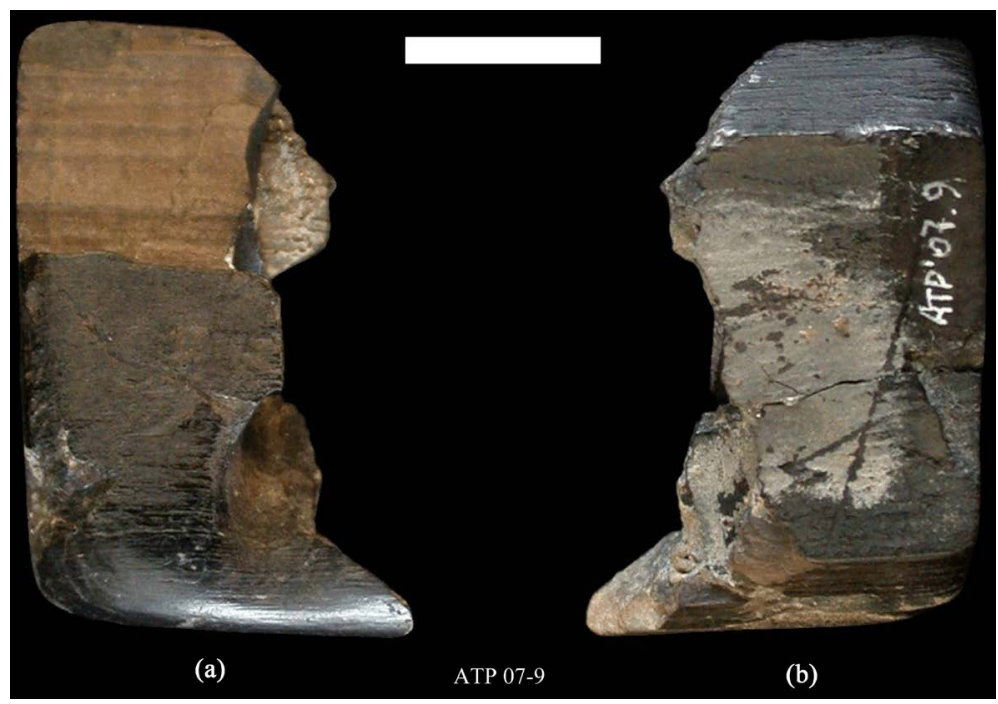

Figure S10. Cuadrangular V-perforated button triangular in cross-section represented in Figure 7(e). The specimen is made out of ivory and is burned. (a) superior view; (b) inferior view. Scale is $1 \mathrm{~cm}$.

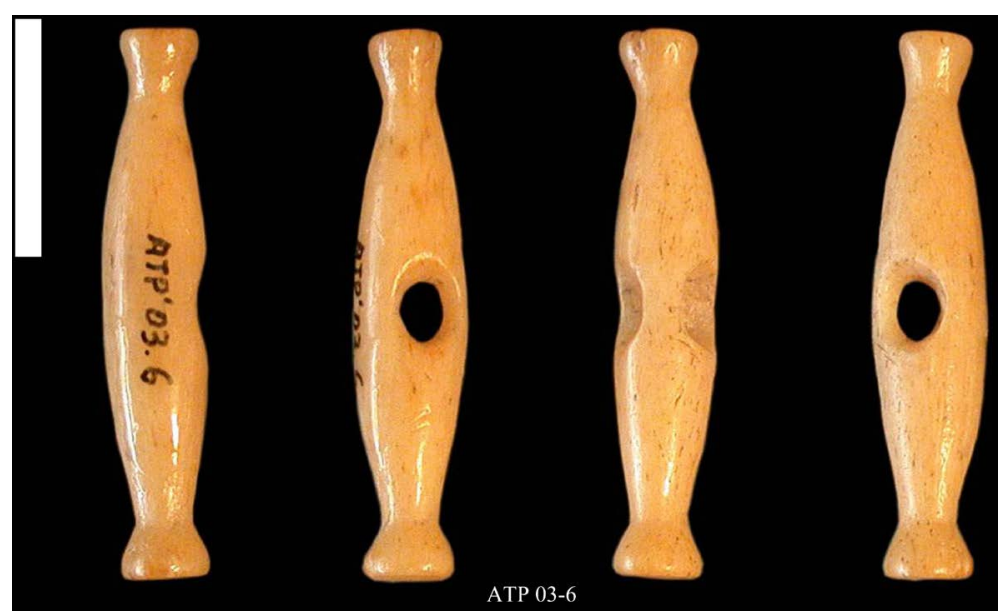

Figure S11. Different views of the button shaped like a spindle with a transversal perforation represented in Figure 7(f). It is similar in shape to the V-perforated tortoiseshell buttons found in some other sites from French Atlantic facade and Northern Iberian Meseta. Made out of bone. Scale is $1 \mathrm{~cm}$. 


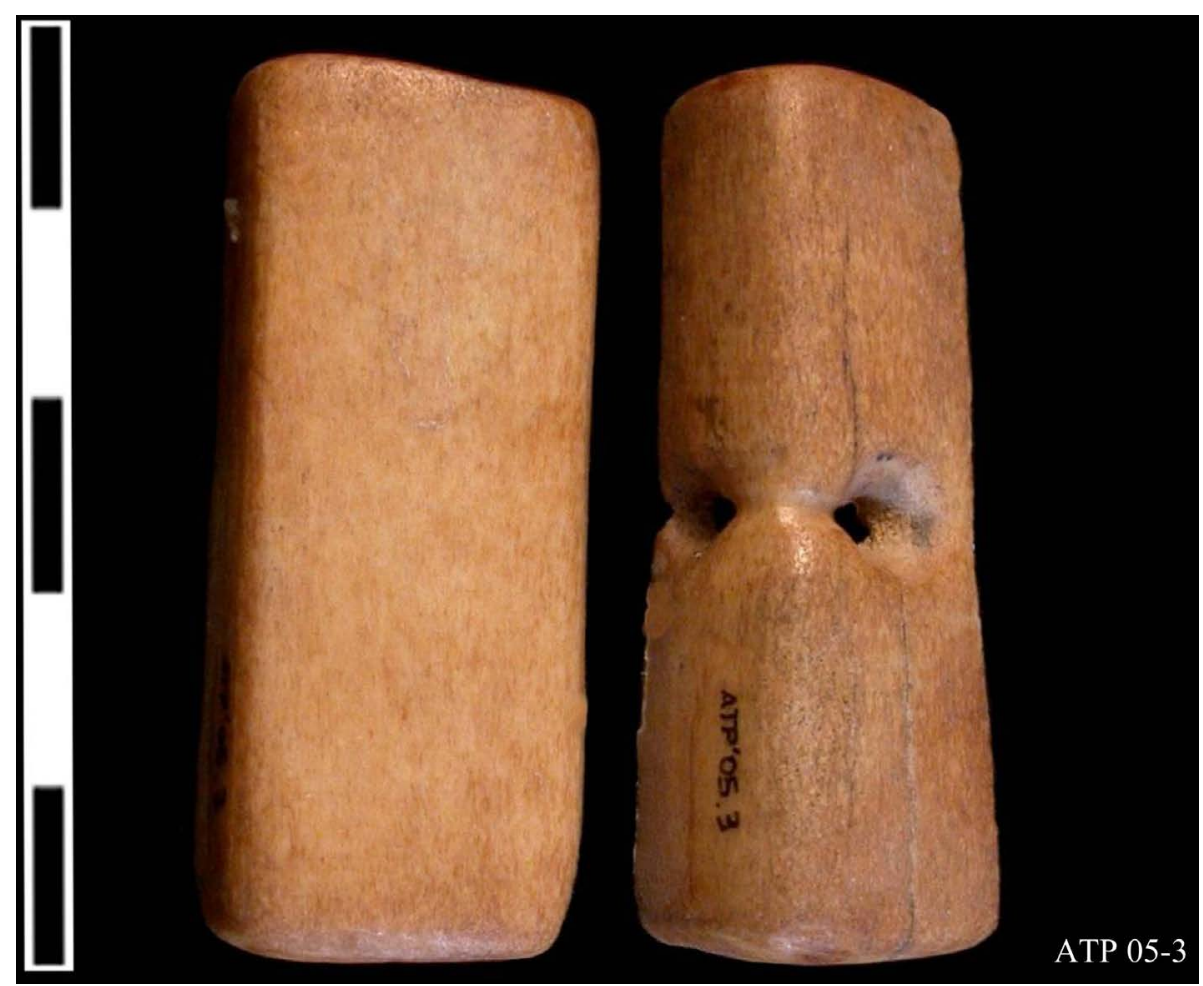

Figure S12. Rectangular V-perforated button triangular in cross-section represented in Figure 7(d). Wear due to use can be clearly seen in the perforations. Made out of bone. Scale is $5 \mathrm{~cm}$.

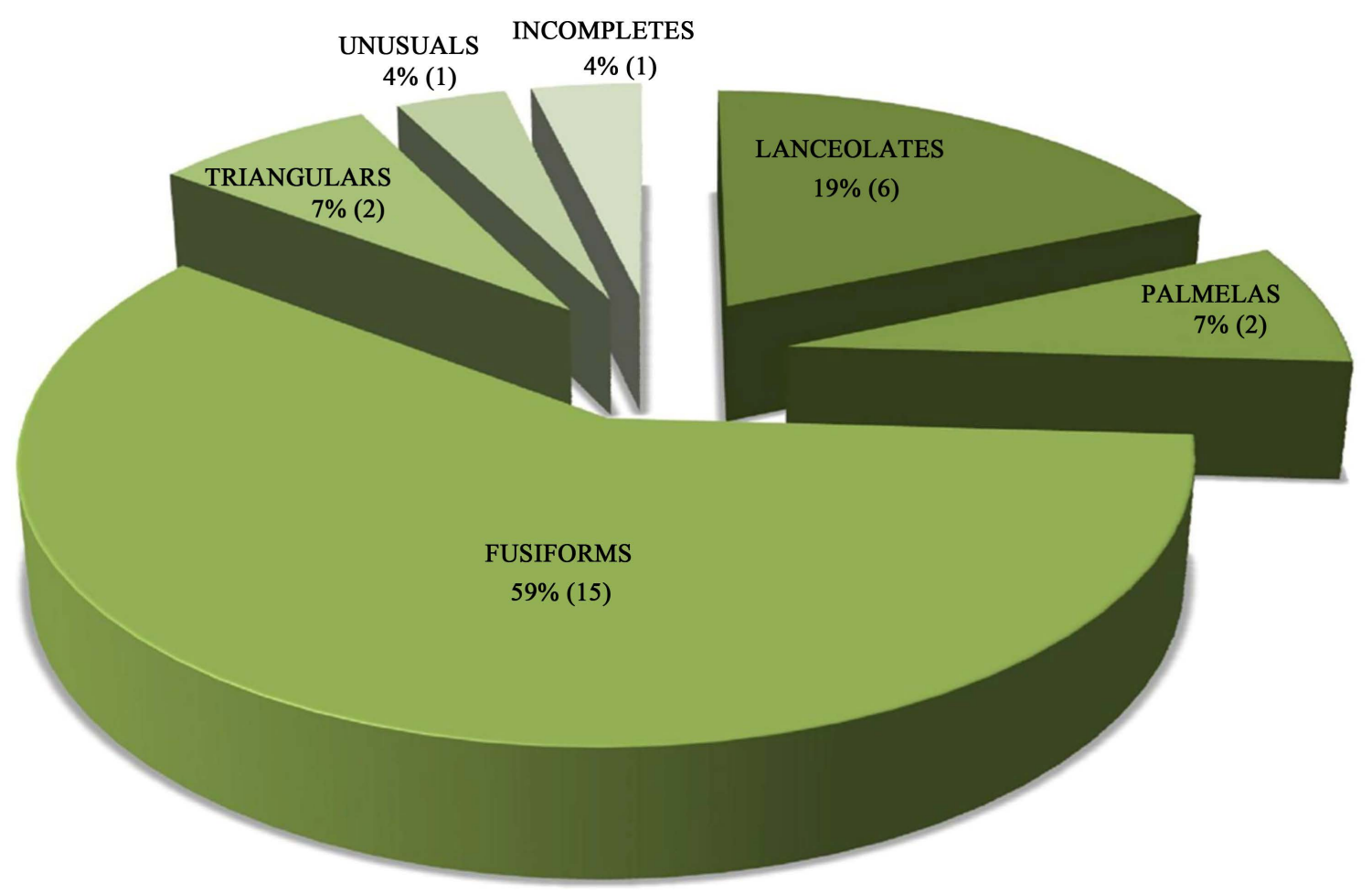

Total number of arrowheads: 27

Figure S13. The 27 arrowheads from El Portalón by type (Table S2). 


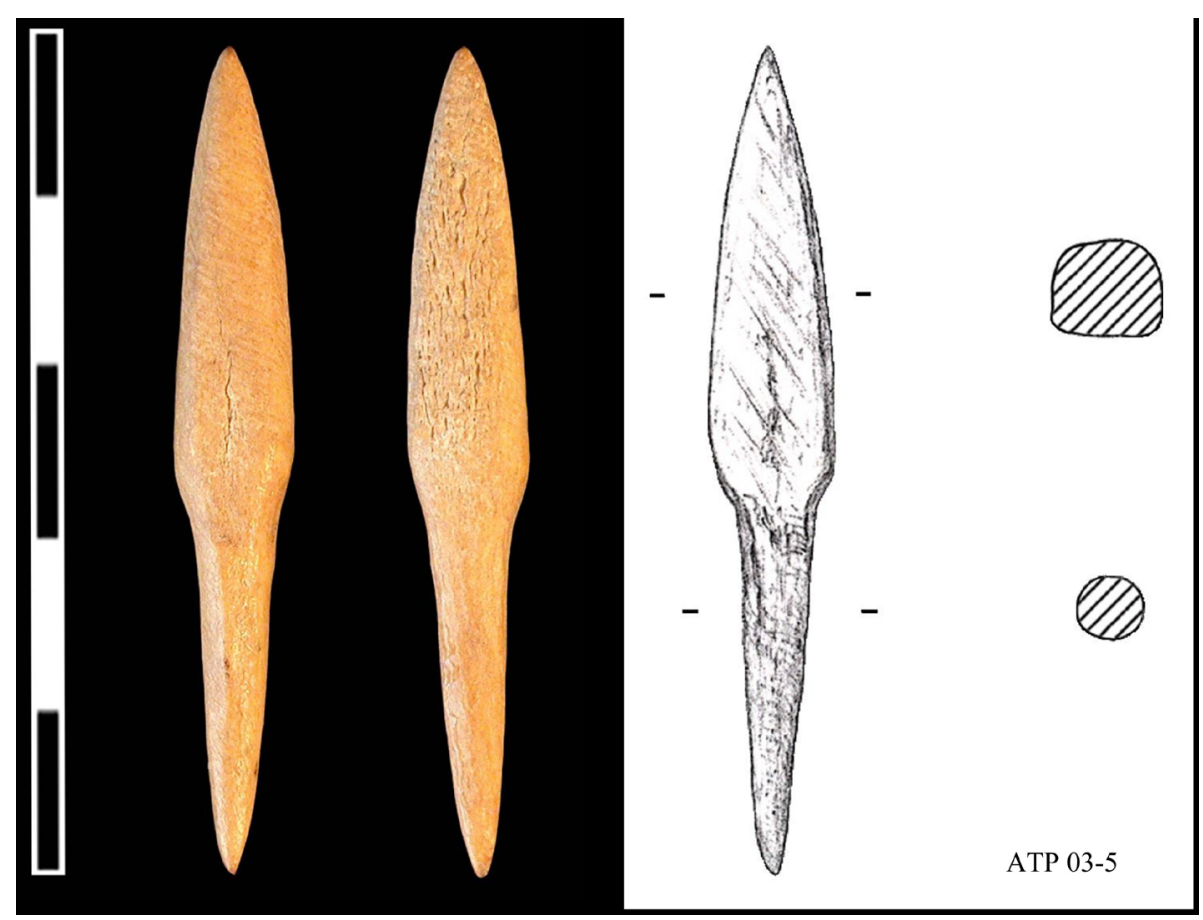

Figure S14. Lanceolate arrowhead from Portalón made out of cervid antler. The body is triangular in shape with cuadrangular cross-section and smoth transition to the stem which is circular in cross- section. Abrasion marks can be appreciated on the body. Scale is $5 \mathrm{~cm}$.

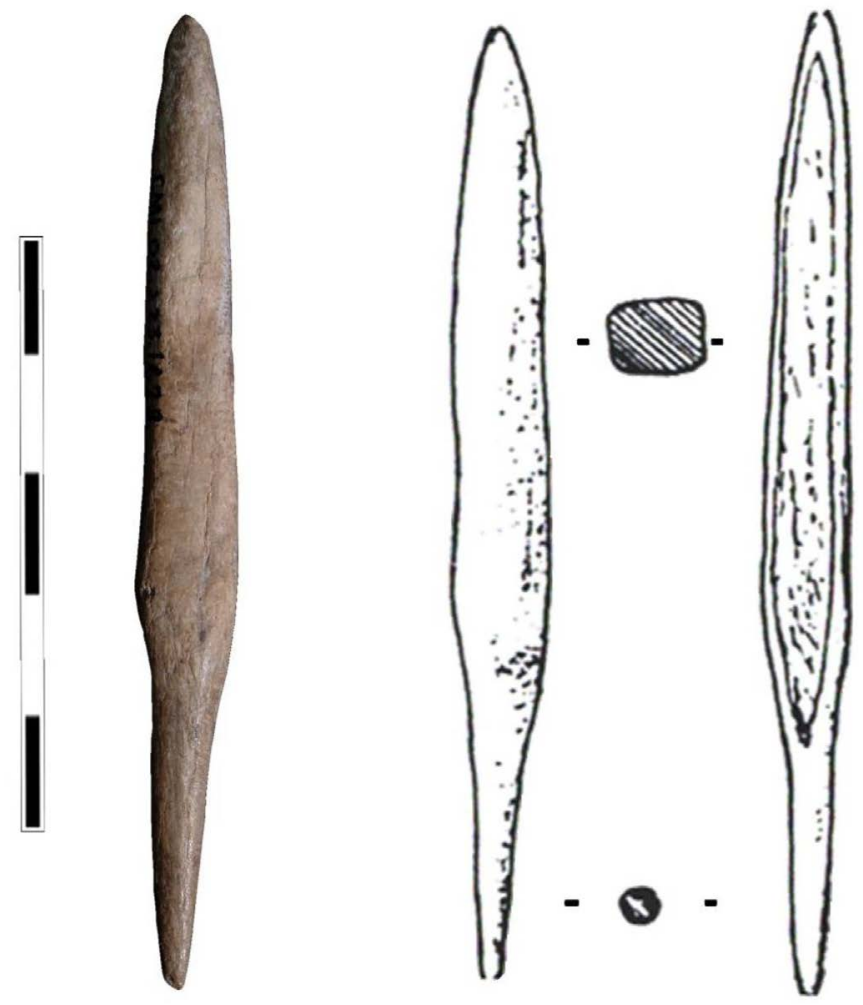

Figure S15. Lanceolate arrowhead from Portalón made out of bone. The body is triangular in shape with cuadrangular cross-section and smoth transition to the stem which is circular in cross-section. Abrasion marks can be appreciated on the body. Scale is $5 \mathrm{~cm}$. 

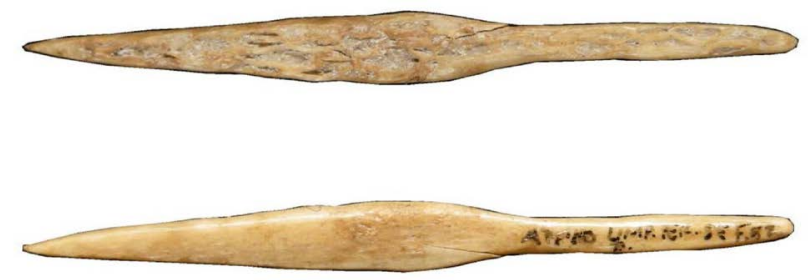

ATP 10 L.P.SE-82

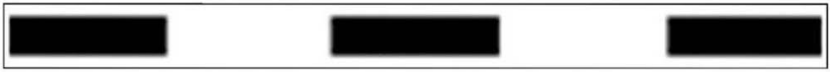

Figure S16. The thinnest lanceolate arrowhead from El Portalón. The body is triangular in shape with cuadrangular cross-section and smoth transition to the stem which is also cuadrangular in cross-section. Made out of antler. Scale is $5 \mathrm{~cm}$.
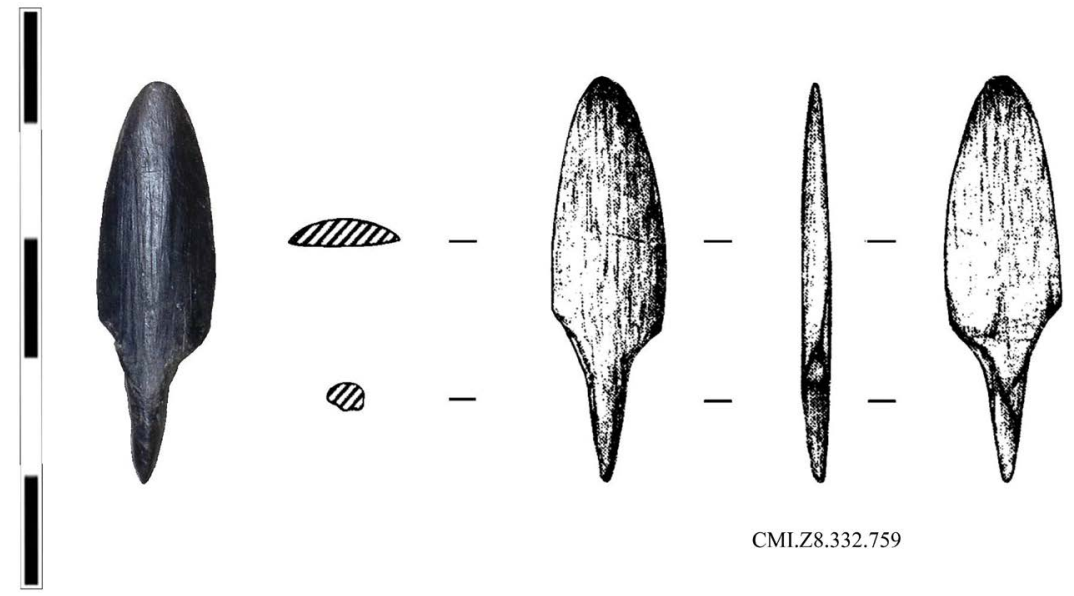

CMI.Z8.332.759

Figure S17. Palmela point from El Portalón made out of bone and burned. The body is triangular and lens-shaped in cross-section. Stem is long and circular in cross-section. The edges are straight and converge to a rounded tip. This kind of arrowheads are usually associated to a Chalcolithic cultural context. Scale is $5 \mathrm{~cm}$.

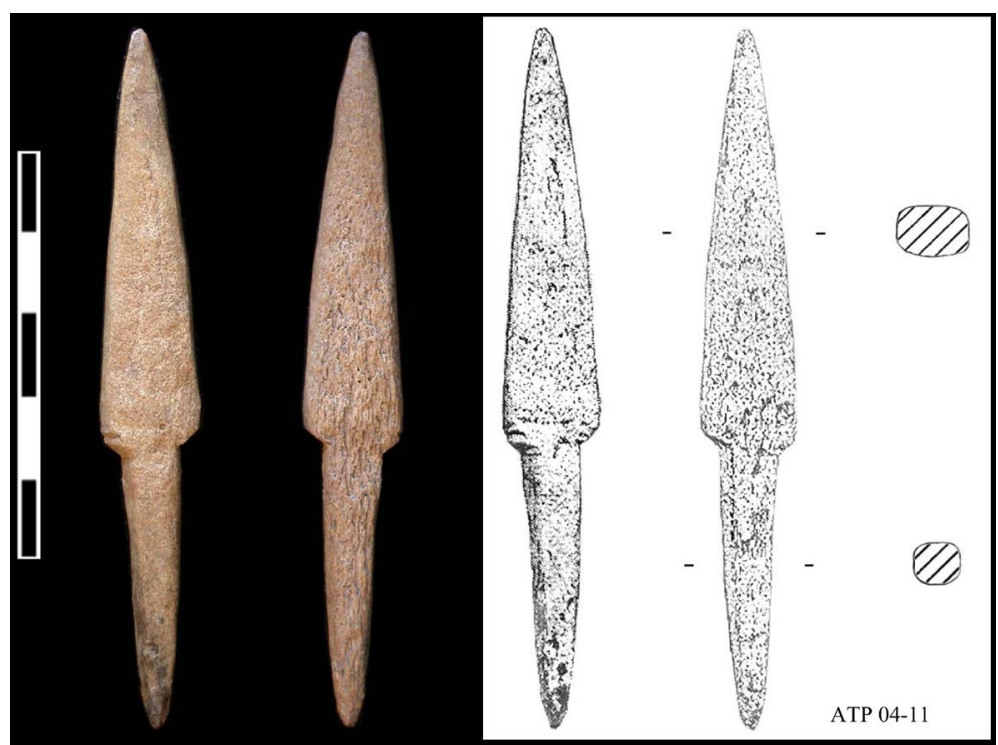

Figure S18. Fusiform arrowhead from Portalón made out of cervid antler. The body is triangular in shape with smoth transition to the stem, both of them cuadrangular in cross-section. Scale is $5 \mathrm{~cm}$. 

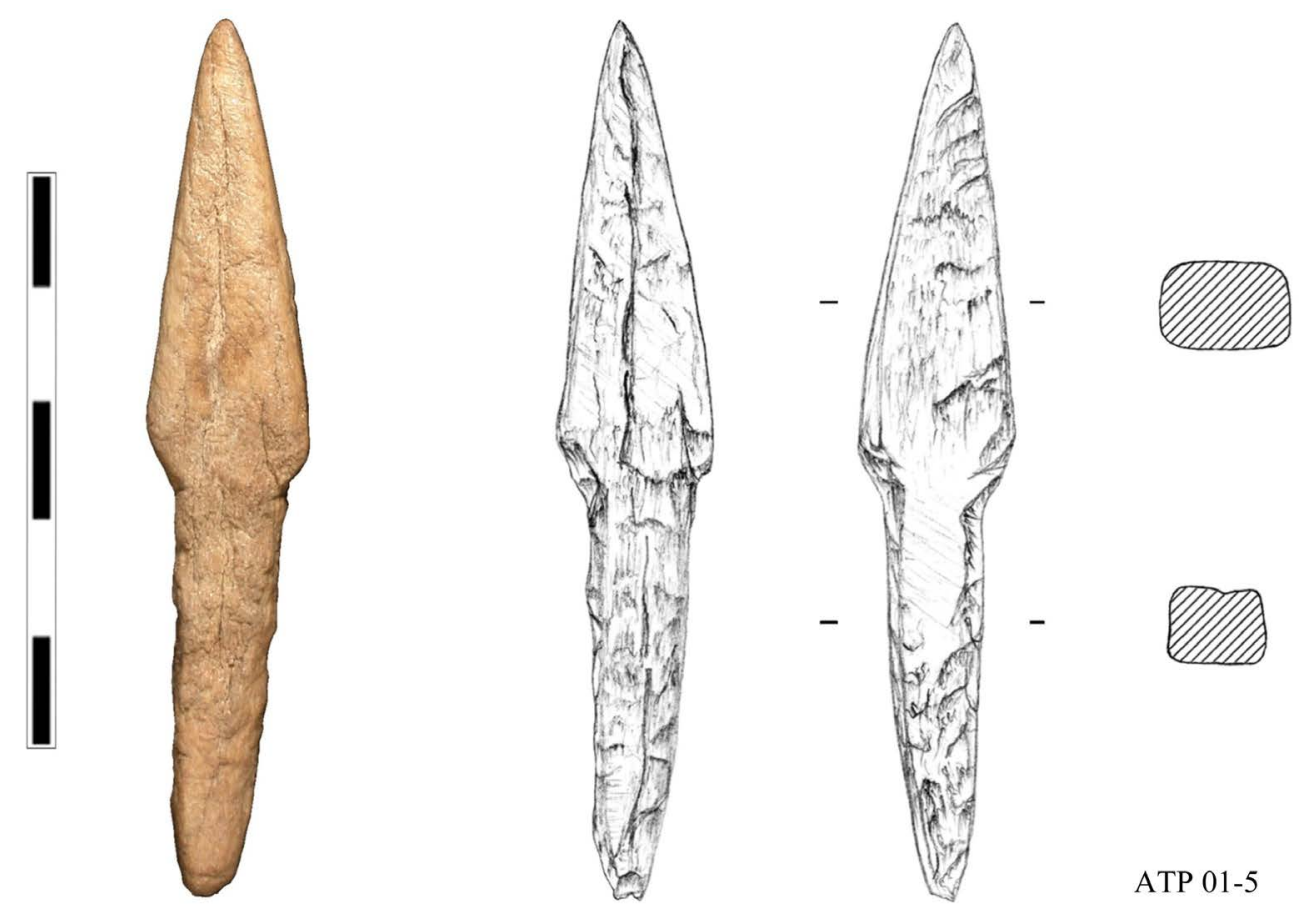

Figure S19. Fusiform arrowhead from Portalón made out of cervid antler. The body and stem are cuadrangular in cross-section. Scale is $5 \mathrm{~cm}$.
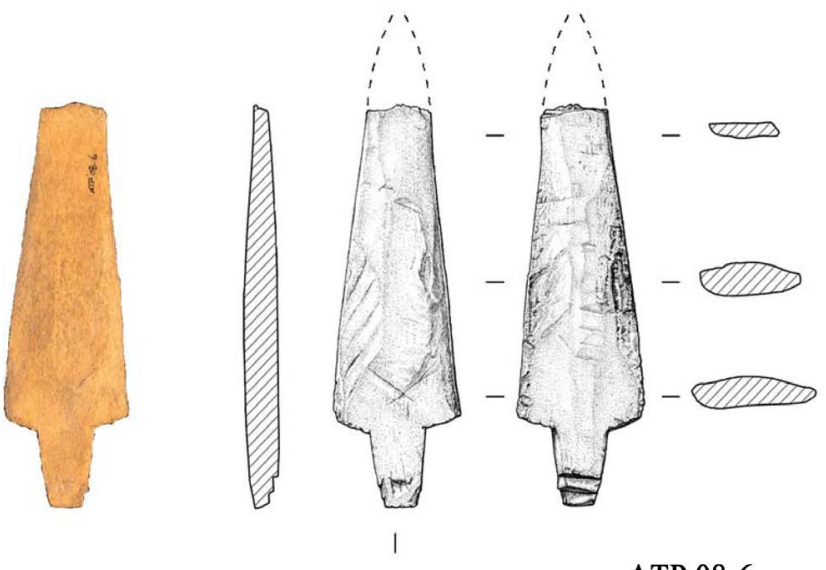

(a)

ATP 08-6

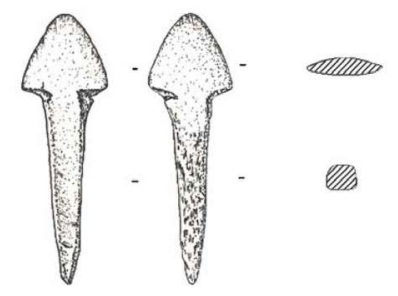

ATP 00-3

(b)

Figure S20. Atypical arrowheads from El Portalón. Both specimens were recovered in the disturbed sediments that fillied the clandestine pit, and their morphology is not age diagnostic. 


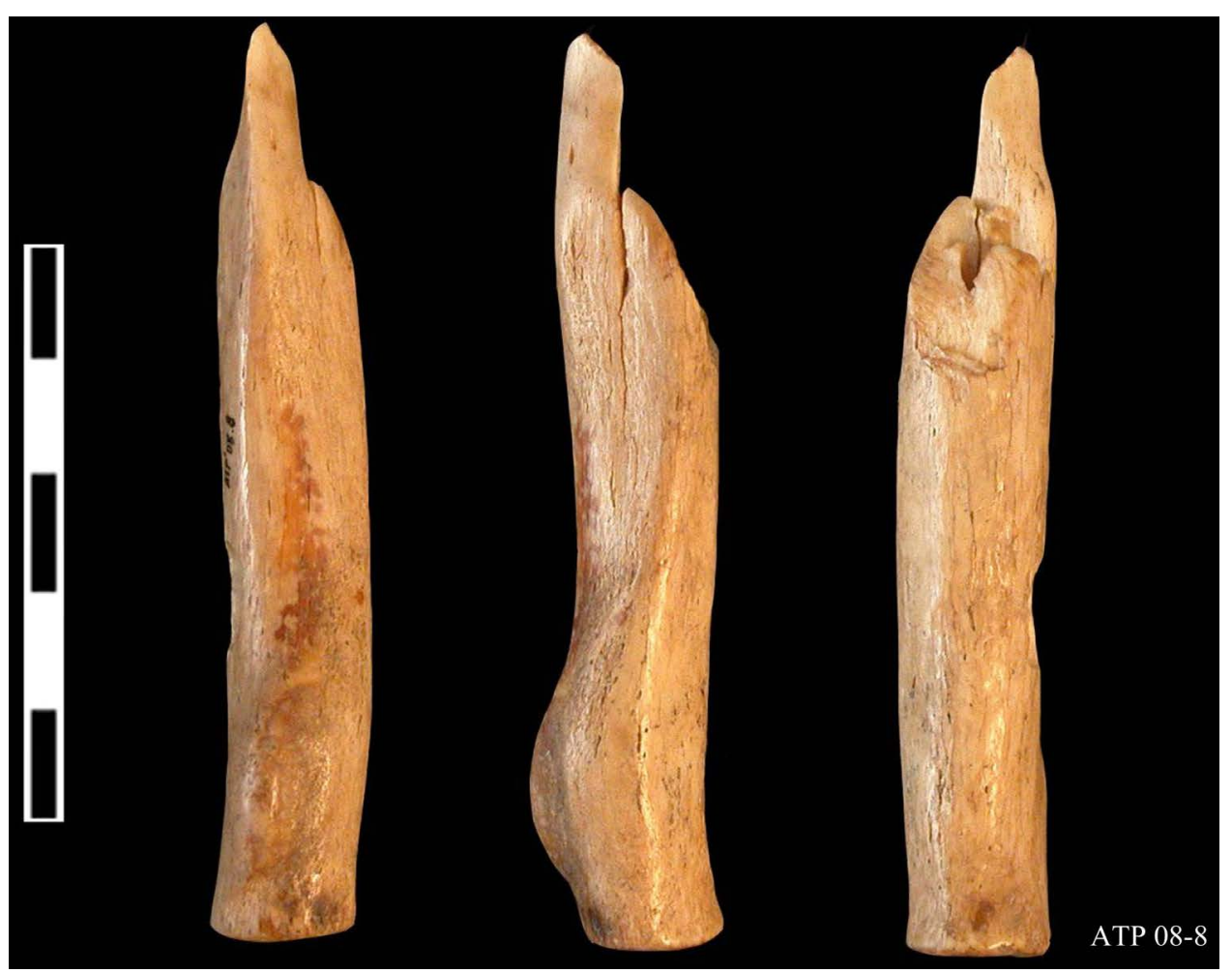

Figure S21. Different views of the awl made on human radius from El Portalón represented in Figure 10. Scale is $5 \mathrm{~cm}$.

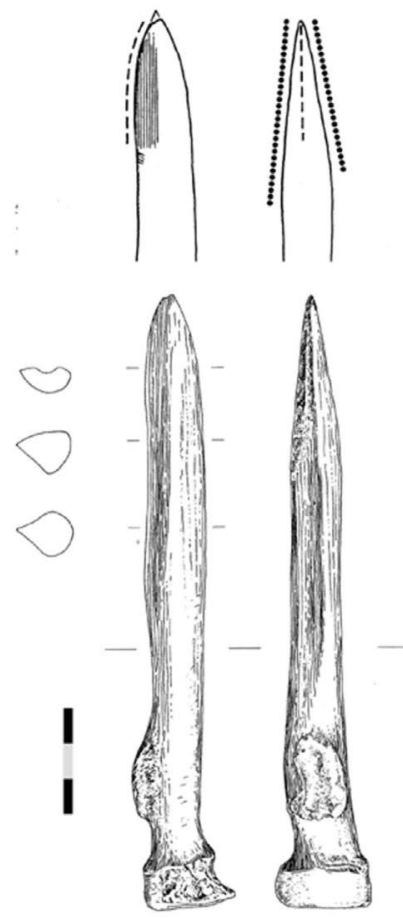

(a)
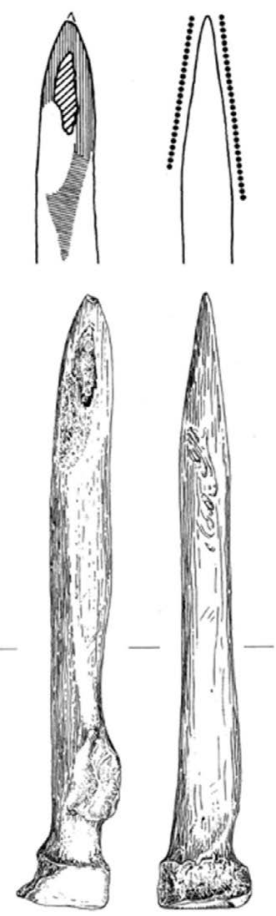
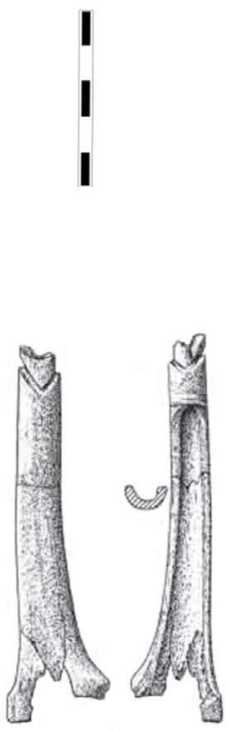

(b)

Figure S22. Two examples of bone tools made of human radius mentioned in the text: (a) Dagger of 16.6 $\mathrm{cm}$ long from Goyet (Belgium) made of a proximal radius (Toussait, 2005); (b) Pointed object from Los Zumacales (Spain) made of a distal radius (modified from Delibes y De Paz, 2000). 


\section{Note S2: Other evidences of tools made on human bones}

There is a $25 \mathrm{~cm}$ long dagger made of a human fibula in the cave of Bédeilhac, situated either in the Chalcolithic (Malvesin-Fabre et al., 1953) or in the early Bronze age (Guilaine, 1972). Also Guilaine in his work refers to a dagger from the Bronze age in the Tuteil Cave (Midi-Pyrénées) made out of a human ulna. Toussait (2005) report a 16.6 centimetre-long object from Goyet (Gesves) (Figure S22(a)) described as a knife or dagger made out of an adult's left radius. This is an excellent example of the problems related to the origin of raw materials as, despite the antiquity of its discovery, until recently the human nature of the bone had not been known. Dated at $2420 \pm 40$ years BP (OxA-8875), it has been compared to the abovementioned French cases as well as to Mechta-el-Arbi in Algeria and to the humerus of a Neolithic child in the Paradou cave in France (Toussait, 2005). Yet another case is that of a Neolithic straightener made out of a human humerus which was recovered from the Nerja Cave in Spain (Adán \& Nieto, 1995).

There are still records of perforated teeth as pendants in the Palaeolithic (molars, premolars, canines and even, a lower jaw; Mújika, 2007-2008).

\section{Note S3: Interpreting marks on human bones}

Cuts, scraping, fractures and other marks are not uncommon on human bones found in burial sites. They are interpreted as being the result of violence or cannibalism for rituals or for food (Boulestin et al., 2009; Graver et al., 2002). Take for example Fronbrégoua in the south of France (Villa et al., 1986), Perrats in Charente (Toussait, 2005) or Herxheim in Renania-Palatinate (Boulestin et al., 2009). Also in the Sierra de Atapuerca, in the El Mirador site, a secondary deposit of human bones from the Bronze Age has been recorded, with fractures and traces of boiling, thus giving rise to speculation on cannibalism (Cáceres et al., 2007).

Etxeberria (2003) points out that we should be cautious in our reasoning, as many of the marks are not the result of human action but are a consequence of postdepositional processes. He points to the same with respect to the two problematic skull-cups found in Gipuzkoa, altered by the taphonomic effect of erosion. García et al. (2010) holds a similar view with respect to the burial site of Avenc dels Dos Forats (Valencia), where numerous marks on the buried bodies correspond to post-depositional action. It would appear to be proven that the dismembering of cadavers, the disorder in the graves and the breakages respond to an interest in arranging the tombs, and to situations deriving from rigor mortis (Delibes and De Paz, 2000; García et al. 2010). We rule out the Basque cases of the tombs of Kalparmuñobarrena, Argabi and Pagobakoitza as deliberate manipulations, although similarities have been reported with other megalithic monuments (Joussaume, 1977; Maury, 1961). There are doubts also about the circles of bone recovered from several European tombs dating from the Metal Age, interpreted as the result of cranial trepanation (Cordier, 2005). Finds like the button made of a human femoral head at the Frères Cave (Ariège) and the beads of the same material at Saint-Vérèdème and Drôme are anecdotal (Arnal, 1954).

In short, we can appreciate a series of burial practices at different times and in different places, which elect who is to be buried, where and under what conditions and creating a complicated burial rite. Secondary or partial burials are common, resulting in an abundance of marks taken as evidence of cannibalism.

\section{References}

Adán, G., \& Nieto, C. (1995). Húmero humano neolítico trabajado de la Cueva de Nerja (Málaga) y su contexto en el ámbito del Estrecho de Gibraltar. Ceuta: II Congreso Internacional El estrecho de Gibraltar, T. I, 105-112.

Arnal, J. (1954). Les boutons perforés en V. Bulletin de la Société Préhistorique Française, 51, 255-268. http://dx.doi.org/10.3406/bspf.1954.3094

Boulestin, B., Zeeb-Lanz, A., Jeunesse, Ch., Haack, F., Arbogast, R. M., \& Denaire, A. (2009). Mass Cannibalism in the Linear Pottery Culture at Herxheim (Palatinate, Germany). Antiquity, 83, 968-982.

http://dx.doi.org/10.1017/S0003598X00099282

Cáceres, I., Lozano, M., \& Saladié, P. (2007). Evidence for Bronze Age cannibalism in El Mirador Cave (Sierra de Atapuerca, Burgos, Spain). American Journal of Physical Anthropology, 133, 899-917. http://dx.doi.org/10.1002/ajpa.20610

Carretero, J. M., Ortega, A. I., Juez, L., Pérez-González, A., Arsuaga, J. L., Pérez-Martínez, R., \& Ortega, M. C. (2008). A Late Pleistocene-Early Holocene archaeological sequence of Portalón de Cueva Mayor (Sierra de Atapuerca, Burgos, Spain). Munibe, 59, 67-80.

Clark, G. (1979). The North Burgos Archaelogical Survey. Bronze and Iron Age archaeology on the Meseta del Norte 
(Province of Burgos, North-Central, Spain). Anthropological Research Papers 19. Arizona: Department of Antropology, Arizona State University.

Cordier, G. (2005). Rondelles crâniennes. Une enquête bibliographique. Bulletin Société Préhistoire francaise, 102, $361-371$.

Delibes, G., \& De Paz Fernández, F.J. (2000). Ídolo-espátula sobre radio humano en el ajuar de un sepulcro megalítico de la Meseta, SPAL. Revista de Prehistoria y Arqueología de la Universidad de Sevilla, 9, 341-350. http://dx.doi.org/10.12795/spal.2000.i9.18

Etxeberría, F. (2003). Estudio antropológico de los restos humanos inhumados e incinerados. Actas de los XIII Cursos Monográficos sobre el Patrimonio Histórico (Reinosa, julio-agosto 2002), 225-248.

García Puchol, O., Cotino, F., Miret, C., Pascual, J. L., McClure, S. B., Molina, L., Alapont, L., Carrión, Y., Morales, J. V., \& Blasco, B. (2010). Cavidades de uso funerario durante el Neolítico final/Calcolítico en el territorio valenciano: Trabajos arqueológicos, en Avenc dels Dos Forats o Cova del Monedero (Carcaixent, Valencia). Archivo de Prehistoria Levantina, XXVIII, 139-206.

Graver, S., Sobolik, K. D., \& Whittaker, J. (2002). Cannibalism or Violent Death Alone? Human Remains at a Small Anasazi Site. In W. D. Haglund, \& M. H. Sorg (Eds.), Advances in Forensic Taphonomy. Method, Theory and Archaeological perpectives (p. 544). New York: CRC Press.

Guilaine, J. (1972). L’Age du Bronze en Languedoc occidental, Roussillon, Ariège. In Mémoires de la Société Préhistorique Française (p. 9).

Joussaume, R. (1977). Le mégalithe de la Pierre-Virante à Xanton-Chassenon (Vendée). L'Anthropologie, Tomo, 81, 5-62.

Malvesin-Fabre, G., Nougier, L. R., \& Robert, R. (1953). Un poigard en os humain dans le Chalcolithique Pyrénén de Bédeilhac (Ariège). Bulletin Société Prehistorique francaise, 50, 405-407.

Maury, J. (1961). La tombe des Anglais. Bulletin de la Société Préhistorique Française, 58, 35-38.

Mujika, J. A. (2007-2008). La gestión de la materia prima ósea en la fabricación de objetos durante la prehistoria. Veleia, 24-25, 531-568.

Toussaint, M. (2005). Un couteau aménagé dans un radius humain protohistorique découvert aux grottes de Goyet (Gesves, province de Namur, Belgique). Bulletin de la Société Préhistorique Française, 102, 625-637. http://dx.doi.org/10.3406/bspf.2005.13145

Villa, P., Courtin, J., Helmer, D., Shipman, P., \& Mahieu, E. (1986). Un cas de cannibalisme au Néolithique. Boucherie et rejet des restes humaines dans la grotte de Fontbrégoua à Salernes (Var). Gallia Préhistoire, 29, 143-171.

http://dx.doi.org/10.3406/galip.1986.2243 